\title{
A SEGUNDA CONFERÊNCIA DAS NAÇÕES UNIDAS SOBRE ASSENTAMENTOS HUMANOS: DOS PREPARATIVOS ÀS ALTERAÇÕES NA LEGISLAÇÃO BRASILEIRA - PARTE II
}

\author{
THE SECOND UNITED NATIONS CONFERENCE ON HUMAN SETTLEMENTS: FROM PREPARATIONS TO \\ CHANGES IN BRAZILIAN LEGISLATION - PART II
}

\section{Josué Mastrodi ${ }^{1}$ \\ Beatriz Duarte Correa de Brito}

\section{RESUMO}

Esse artigo tem por objetivo analisar a legislação federal brasileira sobre direito à moradia, publicada entre 1996 e 2016, verificando se houve influência da Declaração de Istambul, documento final da Segunda Conferência das Nações Unidas sobre Assentamentos Humanos (Habitat II). Após a análise do déficit habitacional brasileiro e do estudo sobre a Habitat II e seu documento final (Parte I), foi realizada uma pesquisa no portal de internet do governo federal (website do Planalto), utilizando os termos 'moradia' e 'habitação'. Dentre as normas filtradas pela pesquisa, 34 normas refletiram princípios e metas da Habitat II, porém somente o Estatuto da Cidade faz referência direta à Conferência.

Palavras-chave: Direito à Moradia. Direito à Cidade. Conferências ONU/Habitat. Programa Minha Casa, Minha Vida. Sustentabilidade.

\section{ABSTRACT}

The objective of this article is to analyze the Brazilian federal legislation on the right to housing, published between 1996 and 2016, to verify if there was influence of the Declaration of Istanbul, final document of the Second United Nations Conference on Human Settlements (Habitat II). After a

\footnotetext{
${ }^{1}$ Doutor em Filosofia e Teoria Geral do Direito pela Universidade de São Paulo (2008). Mestre em Direito da Administração Pública pela Universidade Gama Filho (2003). Especialista em Direito Empresarial pela Pontifícia Universidade Católica de São Paulo (1999). Bacharel em Direito pela Universidade de São Paulo (1994). Professor Titular Categoria A2 da Pontifícia Universidade Católica de Campinas. Membro do corpo docente permanente dos Programas de Pós-Graduação stricto sensu em Direito (PPGD) e em Sustentabilidade (PPGS) da PUC-Campinas. Orientador de mestrado. Líder do grupo de pesquisa 'Direito e Realidade Social' (CNPq/PUC-Campinas). Afiliação:Pontifícia Universidade Católica de Campinas Lattes: http://lattes.cnpq.br/6635472231072927 ORCID: https://orcid.org/0000-0003-4834-0170 E-mail:mastrodi@gmail.com

${ }^{2}$ Mestra em Sustentabilidade pela Pontifícia Universidade Católica de Campinas. Possui graduação em Direito pela Pontifícia Universidade Católica de Campinas. Tem experiência na área de Direito, com ênfase em Direito Público. Possui curso-técnico-profissionalizante em Meio Ambiente pelo Colégio Técnico de Campinas - Unicamp. Afiliação:Pontifícia Universidade Católica de Campinas. Lattes:http://lattes.cnpq.br/1762052051033179. ORCID: https://orcid.org/0000-0001-6638-3700 E-mail:beatriz.brito@mail.com
} 
presentation on the current Brazilian housing deficit and the analysis of the Habitat II and its final document (Part I), a survey on the Internet portal of the federal government was held ("Planalto" website) using the terms 'home' and 'housing'. Among the norms filtered by the research, 34 norms reflect principles and goals of Habitat II, but only the City Statute makes direct reference to the Conference.

Keywords: Right to Housing - Right to The City-Conferences UN / Habitat - My House My Life Program. Sustainability.

\section{INTRODUÇÃO}

O Brasil tornou-se um país predominantemente urbano em meados da década de 1960, porém, nos 20 anos que separaram as duas primeiras Conferências da ONU-Habitat (1976-1996), o país sofreu um intenso processo de urbanização, aumentando de $60,8 \%$ para $77,6 \%$ a população que vivia em áreas urbanas (ONU, 2014). Aliado a esses processos, a discussão sobre moradia ganhava cada vez mais destaque na comunidade internacional, sendo a Habitat II uma das principais Conferências da ONU na década de 1990.

E esse destaque teve alguns reflexos na legislação brasileira, como a edição de uma das principais normas de organização urbana do mundo - o Estatuto da Cidade -, e a criação de um programa habitacional que virou modelo para países vizinhos - o Programa Minha Casa Minha Vida.

A primeira parte desse artigo, previamente publicada, apresentou a importância do tema moradia e analisou a Segunda Conferência das Nações Unidas sobre Assentamentos Humanos, realizada em 1996, em Istambul, na Turquia, em especial, seu documento final: a Declaração de Istambul.

Nessa segunda parte, analisaremos as normas brasileiras federais (medidas provisórias, decretos, leis, leis complementares, emendas constitucionais) relacionadas ao tema moradia, para avaliarmos se a Habitat II influenciou direta ou indiretamente o ordenamento jurídico brasileiro.

Para tanto, foi feita uma busca no portal de internet do governo federal (site do Planalto), utilizando os termos "moradia" e "habitação" ${ }^{3}$. Após uma breve análise, foram excluídas as normas que possuem esses termos, mas não tratam desse tema ${ }^{5}$. Outras normas tratam apenas de questões

${ }^{3}$ O termo "casa" não foi utilizado, pois todas as normas que continham o termo "Casa Civil" eram filtradas, perdendo, assim, o filtro da pesquisa.

${ }^{4}$ Apesar da diferença de conceitos entre moradia e habitação, nesse trabalho, os termos foram utilizados como sinônimos.

${ }^{5}$ O Decreto Legislativo n. 42, de 20 de maio de 1998, dispõe sobre a construção de um prédio para a ampliação das instalações da embaixada do Brasil em Luanda, capital da Angola (BRASIL, 1998a).

O Decreto de 27 de agosto de 2004, que trata do desenvolvimento sustentável do Município de Alcântara no Maranhão (BRASIL, 2004c). 
administrativas e burocráticas ${ }^{6}$, sem qualquer impacto no direito à moradia, por isso, não serão analisadas ao longo do texto. Dessa forma, restaram 41 normas, entre leis ordinárias, leis complementares, medidas provisórias e decretos, a serem estudas a seguir, em ordem cronológica.

Lei n. 12.415, de 09 de junho de 2011, que alterou o Estatuto da Criança e do Adolescente para determinar que alimentos provisórios sejam fixados cautelarmente em favor da criança ou adolescente cujo agressor seja afastado da moradia comum por determinação judicial (BRASIL, 2011b).

${ }^{6}$ O Decreto n. 2.450, de 30 de dezembro de 1997, que prorrogou a validade da inscrição em Restos a Pagar dos Programas de Habitação, de Saneamento e de Infraestrutura (BRASIL, 1997b).

Lei n. 9.649 de 27 de maio de 1998, precedida por uma série de medidas provisórias (1.549, 1.642, 1.651), trata da organização da Presidência da República e de seus Ministérios. Versando sobre questões estritamente administrativas, como a extinção dos cargos de Secretário das Secretarias de Habitação; de Saneamento; e da Promoção Humana (BRASIL, 1998b).

O Decreto n. 2.921, de 30 de dezembro de 1998, que prorrogou a validade da inscrição em Restos a Pagar dos Programas de Habitação, de Saneamento e de Infraestrutura (BRASIL, 1998c).

A Medida Provisória n. 2.158, de 24 de agosto de 2001, que tratou da não integração do auxílio-moradia à remuneração do beneficiário, para não desconto do imposto de renda (BRASIL, 2001c).

A Medida Provisória n. 2.181, de 24 de agosto de 2001, que, precedida pelas MPV n. 1.655/98, MPV n. 1.682/98, MPV n. 1.755/98, MPV n. 1.868/99, MPV n. 1.885/99 e MPV n. 2.103/00, dispõe sobre operações financeiras entre o Tesouro Nacional e outras entidades (BRASIL, 2001d).

A Lei n. 10.885, de 17 de junho de 2004, originada na MPV n. 175/04, que trata das relações jurídicas entre mutuário e instituição financiadora e entre mutuário e seguradora no âmbito do FCVS (BRASIL, 2004b).

Decreto n. 5.345 de 18 de janeiro de 2005, que trata de questões burocráticas de contratos do PSH (BRASIL, 2005a).

Decreto n. 5.892, de 12 de setembro de 2006, que trata de empréstimos e financiamentos no âmbito do SFH (BRASIL, 2006d).

Decreto n. 5.955 de 07 de novembro de 2006, que dispõe sobre a estrutura de alguns Ministérios (BRASIL, 2006g).

Lei n. 11.434, de 28 de dezembro de 2006, conversão da MPV n. 321/2006, trata de contratos celebrados no âmbito do SFH (BRASIL, 200h).

Lei n. 11.578, de 26 de novembro de 2007, resultante da conversão da MPV n. 387/07, que definiu que a operacionalização do PSH nos exercícios de 2007 e 2008 caberia ao Poder Executivo (BRASIL, 2007h).

Decreto n. 6.820, de 13 de abril de 2009, que dispõe sobre a composição e as competências do Comitê de Participação no Fundo Garantidor da Habitação Popular - CPFGHab e sobre a forma de integralização de cotas no Fundo Garantidor da Habitação Popular - FGHab (BRASIL, 2009a).

Lei $n$. 12.024, de 27 de agosto de 2009, que trata do pagamento de tributos pelas construtoras parceiras do PMCMV (BRASIL, 2009c).

Medida Provisória n. 478, de 29 de dezembro de 2009, que dispõe sobre a extinção da Apólice do Seguro Habitacional do SFH (BRASIL, 2009e).

Decreto n. 7.161, de 29 de abril de 2010, que autorizou o resgate de cotas do Fundo Garantidor da Habitação Popular (FGHab), do Fundo Garantidor de Investimentos (FGI) e do Fundo Garantidor de Operações (FGO), em ações de emissão da Centrais Elétricas Brasileiras S.A. (ELETROBRÁS) (BRASIL, 2010a).

Decreto n. 7.366, de 25 de novembro de 2010, que permitiu a integralização de cotas do FGHab (BRASIL, 2010c).

Decreto n. 7.367, de 25 de novembro de 2010, que dispôs sobre a forma de habilitação e co-habilitação ao REIDI (BRASIL, 2010d).

Lei n. 12.409, de 25 de maio de 2011, que trata do Seguro Habitacional. SFH (BRASIL, 2011a).

Lei n. 12.712, de 30 de agosto de 2012, que tratou da concessão de garantias pela Agência Brasileira Gestora de Fundos Garantidores e Garantias S.A. - ABGF contra riscos em operações de crédito habitacional (BRASIL, 2012).

Lei n. 13.000, de 18 de junho de 2014, que tornou obrigatória a intimação da CEF nos processos que tramitam na Justiça Comum Estadual que tenham por objeto a extinta apólice pública do Seguro Habitacional do SFH (BRASIL, 2014).

Lei n. 13.137, de 19 de junho de 2015, que trata do pagamento mensal unificado por empresas construtoras de unidades habitacionais (BRASIL, 2015b). 


\section{Lei n. $9.300 / 96$}

Publicada no Diário Oficial de 30 de agosto de 1996, a Lei n. 9.300 alterou a Lei n. 5.889, de 8 de junho de 1973, que regulamenta o trabalho rural, para determinar que a moradia do trabalhador rural, cedida por seu empregador, não integra o salário daquele, desde que expresso em contrato (BRASIL, 1996a). A Lei de 1973 já permitia o desconto de até $20 \%$ do salário do trabalhador rural pela ocupação da moradia fornecida pelo empregador, vindo a Lei de 1996 apenas regulamentar essa questão, sem qualquer influência direta sobre o direito à moradia, não sendo, portanto, reflexo da Habitat II.

\section{Lei n. 9.514/97}

Publicada no Diário Oficial de 21 de novembro de 1997, a lei instituiu o Sistema de Financiamento Imobiliário (SFI), que tinha por finalidade financiar imóveis em geral, e estabeleceu algumas regras sobre esses financiamentos (BRASIL, 1997a). Esse Sistema facilitaria a aquisição da casa própria, portanto, é uma norma voltada à promoção do direito de propriedade, e não do direito à moradia. E, em que pese a Declaração de Istambul preveja financiamentos para garantir moradia adequada a todos, o financiamento não deve ser abusivo, sob pena de ir contra a sustentabilidade econômica do beneficiário. Essa lei, porém, não limita essa taxa de juros. Dessa forma, a norma não vai ao encontro da Habitat II.

\section{Lei n. $9.785 / 99$}

Publicada no Diário Oficial de 10 de fevereiro de 1999, a Lei n. 9.785/99 alterou o Decreto-Lei que regulamenta a desapropriação por utilidade pública, bem como a Lei de Registros Públicos e a Lei de Parcelamento do Solo Urbano (BRASIL, 1999a).

Em relação ao Decreto-Lei n. 3.365/41, que regulamenta a desapropriação por utilidade pública, a lei alterou seu artigo 5ㅇ, i, para substituir a expressão "loteamento de terreno edificado ou não", por "parcelamento do solo, com ou sem edificação" (BRASIL, 1999a), sendo uma alteração estritamente ortográfica, para adequação de termos legais, que não influenciou diretamente no direito à moradia. A Lei também incluiu ao artigo 50 do Decreto-Lei o §3ํㅡ, que determina que: “Ao imóvel desapropriado para implantação de parcelamento popular, destinado às classes de menor renda, não se dará outra utilização nem haverá retrocessão" (BRASIL, 1999a).

Esse dispositivo reflete a sustentabilidade social proposta pela Habitat II, por meio do combate à pobreza e promoção de moradia adequada a todos. Ao privilegiar as classes de menor renda, o 
dispositivo busca uma igualdade de condições entre as camadas sociais e reflete princípios da Declaração de Istambul e, principalmente, da Declaração de Vancouver, que expressa a necessidade de atenção prioritária aos mais pobres.

Já a Lei n. 6.015/73, que trata dos Registros Públicos, foi alterada para determinar o registro de: “imissão provisória na posse, e respectiva cessão e promessa de cessão, quando concedido à União, Estados, Distrito Federal, Municípios ou suas entidades delegadas, para a execução de parcelamento popular, com finalidade urbana, destinado às classes de menor renda" (BRASIL, 1999a). Apesar de o dispositivo tratar de parcelamento popular voltado às classes de menor renda, o conteúdo é estritamente burocrático e não reflete princípios da Habitat II.

A Lei n. 6.766/79, que trata do parcelamento de solo urbano, por sua vez, sofreu diversas alterações. Primeiramente, a nova lei determinou a obrigatoriedade de instalação de infraestrutura básica (como saneamento básico, energia elétrica e vias de acesso) para que o parcelamento de solo seja autorizado (BRASIL, 1999a). E, em que pese a exposição de motivos da Lei não se referir à Conferência da ONU, esse dispositivo vai ao encontro do item 4 da Declaração de Istambul, que afirma que, para melhorar a qualidade de vida nos assentamentos humanos, é necessário garantir a infraestrutura básica.

A Lei incluiu, também, como requisito para loteamentos a proporcionalidade entre equipamentos públicos e densidade populacional (BRASIL, 1999a), o que vai ao encontro do item 4 da Declaração de Istambul, que considera insustentável a concentração populacional excessiva.

Essa Lei estabeleceu, ainda, que: "são considerados de interesse público os parcelamentos vinculados a planos ou programas habitacionais de iniciativa das Prefeituras Municipais e do Distrito Federal, ou entidades autorizadas por lei, em especial as regularizações de parcelamentos e de

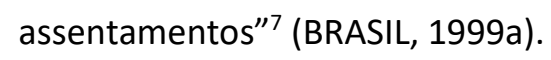

As demais alterações introduzidas pela Lei n. 9.785/99 à Lei n. 6.766/79 tratam de questões burocráticas e não refletem princípios da Habitat II.

\section{Lei $\mathrm{n}$. 9.934/99}

Publicada no Diário Oficial de 21 de dezembro de 1999, a Lei n. 9.934/99 determinou a redução em $20 \%$ (vinte por cento) das despesas cartorárias com atos notariais, registro e averbações de imóveis residenciais resultantes de programas governamentais voltados à construção de habitações populares para população de baixa renda, desde que o imóvel tenha até sessenta e nove metros quadrados de

\footnotetext{
${ }^{7}$ Nos termos do artigo $3^{\circ}$, que incluiu o artigo 53-A à Lei 6.766/79.
} 
área construída, em terreno de até duzentos e cinquenta metros quadrados e tenha sido construído pelo sistema de mutirão e autoconstrução orientada (BRASIL, 1999b).

A Lei 6.015/73, que regula os registros públicos, já previa (a partir da Lei n. 6.941/81) a redução das custas cartorárias em $50 \%$ (cinquenta por cento) para a primeira aquisição imobiliária, para fins residenciais, financiada pelo SFH, bem como outras porcentagens de reduções para imóveis financiados pelas COHABs, variando o desconto de acordo com o tamanho do imóvel (BRASIL, 1981a). E a Lei $n$. 9.934/99 veio complementar esse artigo, estendendo os descontos para as construções em sistema de mutirão e autoconstruções orientadas (BRASIL, 1999b).

Ao reduzir os custos cartorários, a lei facilita a aquisição da casa própria pelas pessoas de baixa renda e o intuito dessa lei não é o direito de propriedade, mas o direito à moradia, visto que privilegia a população de baixa renda que constrói casas pelo sistema de mutirão e autoconstrução sustentada. Dessa forma, a lei vai ao encontro da Declaração de Istambul e, mais especificamente, à Declaração de Vancouver.

\section{Decreto n. $3.298 / 99$}

O Decreto 3.298, de 20 de dezembro de 1999, instituiu a Política Nacional para a Integração da Pessoa Portadora de Deficiência, que determina que cabe ao Poder Público "assegurar à pessoa portadora de deficiência o pleno exercício de seus direitos básicos"8 (BRASIL, 1999c), inclusive habitação. Ou seja, determina a inclusão das pessoas com deficiência, respeitadas suas peculiaridades. A norma, portanto, vai ao encontro do documento final da Habitat II, que determina em seu item 7 a total acessibilidade para pessoas com deficiências.

\section{Emenda Constitucional n. 26/00}

Mais importante emenda à Constituição relacionada ao direito à moradia, a EC n. 26, de 14 de fevereiro de 2000, incluiu no rol dos direitos sociais, previstos no artigo 60 da CF, o direito à moradia. $\mathrm{E}$ a classificação da moradia como um direito social é de extrema importância para sua promoção, visto que é dever do Estado garantir os direitos sociais, conhecidos como direitos de segunda dimensão ou direitos prestacionais, inclusive, destinando recursos públicos à promoção desses direitos, que garantiriam uma igualdade material (MASTRODI; SILVA, 2012). E durante a votação da PEC 601, que precedeu a EC n. 26, o Deputado Inácio Arruda ressaltou isso:

\footnotetext{
${ }^{8}$ Nos termos do artigo 2o do Decreto 3.298/99.
} 
... [que a] Constituição acolha a moradia como direito social. Alguns consideram pouco, porque já há citações à moradia em vários trechos da Constituição. Mas isso não bastava. Era preciso estar claro na Constituição que moradia é um direito social, pois só assim o movimento efetivamente social do País pode cobrar à altura, dos Governos Federal, Estadual e Municipal, que garantam recursos, no Orçamento Geral da União e nos orçamentos estaduais e municipais, para oferecer moradia à parcela da população sem renda ou de baixa renda, em nosso País, segmento em que se registra metade do déficit habitacional brasileiro. Cerca de 5 milhões de moradias, no Brasil, não foram e não são atendidas por nenhum programa social ou de Governo (ARRUDA, 2000).

Proposta em 1998, ou seja, dois anos após a Habitat II, os autores da PEC se basearam justamente na Conferência da ONU, que evidenciou o caráter humano do direito à moradia, sendo o Brasil um dos responsáveis por defender essa classificação:

A questão do direito à moradia tem sido objeto de aceso e polarizado debate social tanto em nível nacional como internacional. Fóruns, entidades de classe, entidades governamentais e não-governamentais têm-se reunido nesses dois últimos anos com vistas ao maior encontro de todos os tempos sobre o tema: a Conferência Habitat II, convocada pela Organização das Nações Unidas (ONU) e realizada no período de 03 a 14 de junho deste ano.

Para esse evento, o Brasil foi indicado relator da parte da Agenda do Habitat (carta de intenções da Conferência) que trata do "direito à moradia". Coube-lhe, assim, a difícil tarefa de justificar, frente a países como Japão, Estados Unidos e Coréia (que se posicionam contra a inclusão desse termo na Agenda), a urgente necessidade de se reconhecer a moradia como um direito social (CÂMARA DOS DEPUTADOS, 1998, p. 10).

Na Justificativa à PEC, o Senador Mauro Miranda, autor da proposta, também advertiu sobre a situação crítica da moradia de milhões de brasileiros e da necessidade de se reconhecer a moradia como um direito:

As atuais condições de moradia de milhões de brasileiros chegam a ser deprimentes e configuram verdadeira "chaga social" para grande parte das metrópoles do País. Faz-se, portanto, urgente que se dê início a um processo de reconhecimento da moradia como a célula básica, a partir da qual se desenvolvem os demais direitos do cidadão, já reconhecidos por nossa Carta Magna: a saúde, o trabalho, a segurança, o lazer, entre outros. Sem a moradia o indivíduo perde a identidade indispensável ao desenvolvimento de suas atividades, enquanto ente social e produtivo se empobrece e se marginaliza. Com ele se empobrece, invariavelmente, a Nação (CÂMARA DOS DEPUTADOS, 1998, p. 10).

Já o Deputado Inocêncio Oliveira, observou que o Brasil foi a décima sétima nação a incluir a moradia em sua Carta Magna como um direito social e que essa seria uma intenção a ser cumprida, possibilitando ao Governo "traçar uma política habitacional para o nosso País, dirigida sobretudo aos segmentos mais pobres, mais humildes e mais necessitados, a fim de que possamos construir uma 
sociedade mais justa, mais fraterna, mais humana e mais desenvolvida" (DIÁRIO DA CÂMARA DOS DEPUTADOS, 2000, p. 04016).

O Deputado Ricardo Izar, então coordenador da Frente Parlamentar da Habitação e Desenvolvimento Urbano, lembrou que a EC por si só não seria suficiente para resolver o problema do déficit habitacional brasileiro, mas que seria o primeiro passo para dar início a uma tão urgente e esperada política habitacional (DIÁRIO DA CÂMARA DOS DEPUTADOS, 2000, p. 04016).

E a Deputada Telma de Souza voltou a fazer referência à Habitat II, salientando que a Câmara dos Deputados enviou uma Comissão de Deputados para Istambul, para participar da Conferência da ONU, demonstrando um desejo do Parlamento de incluir o direito à moradia na nossa Constituição (DIÁRIO DA CÂMARA DOS DEPUTADOS, 2000, p. 04016).

Esse dispositivo, portanto, não somente vai totalmente ao encontro da Declaração de Istambul, como se baseia ${ }^{9}$ na Conferência da ONU/Habitat.

\section{Emenda Constitucional n. $31 / 00$}

Outra importante EC relacionada ao direito à moradia foi publicada no ano 2000, a EC n. 31, de 14 de fevereiro de 2000, que criou o Fundo de Combate e Erradicação da Pobreza.

Constituído por parcelas da Contribuição Provisória sobre Movimentação ou Transmissão de Valores e de Créditos e Direitos de Natureza Financeira (CPMF); do Imposto sobre Produtos

\footnotetext{
9 "A questão do direito à moradia tem sido objeto de aceso e polarizado debate social., tanto em nível nacional como internacional. Fóruns, entidades de classe, entidades governamentais e não governamentais têm-se reunido nesses dois últimos anos com vistas ao maior encontro de todos os tempos sobre o tema: a Conferência Habitat II, convocada pela Organização das Nações Unidas (ONU) e realizada no período de 03 a 14 de junho deste ano.

Para esse evento, o Brasil foi indicado relator da parte da Agenda do Habitat (carta de intenções da Conferência) que trata do "direito à moradia". Coube-lhe, assim, a difícil tarefa de justificar, frente a países como Japão, Estados Unidos e Coreia (que se posicionaram contra a inclusão desse termo na Agenda), a urgente necessidade de se reconhecer a moradia como um direito social.

A participação ativa brasileira em tão importante evento, de caráter mundial., coloca-nos em posição delicada, principalmente quando se verifica, em meio de uma situação eminentemente crítica das áreas urbanas brasileiras, uma lacuna na própria Constituição Federal, que não reconhece a moradia como um direito real, como a saúde, o lazer, o trabalho etc. Mais delicada, ainda, fica a situação do Brasil quando, sabedores da realização da Conferência, os "sem-teto" de todo o País, já bastante organizados, ameaçam "pipocar ocupações de terrenos" na periferia das grandes cidades - conforme se lê nos mais renomados jornais do País.

As atuais condições de moradia de milhões de brasileiros chegam a ser deprimentes e configuram verdadeira "chaga social" para grande parte das metrópoles do País. Faz-se, portanto, urgente que se dê início a um processo de reconhecimento da moradia como a célula básica, a partir da qual se desenvolvem os demais direitos do Cidadão, já reconhecidos por nossa Carta Magna: a saúde, o trabalho, a segurança, o lazer, entre outros. Sem a moradia, o indivíduo perde a identidade indispensável ao desenvolvimento de suas atividades, enquanto ente social e produtivo, se empobrece e se marginaliza. Com ele se empobrece, invariavelmente, a Nação." (CANEDO, 1998, p. 29023).
} 
Industrializados (IPI); do imposto sobre grandes fortunas ${ }^{10}$; de dotações orçamentárias; de doações, de qualquer natureza, de pessoas físicas ou jurídicas do País ou do exterior, o Fundo tinha por objetivo: "Viabilizar a todos os brasileiros o acesso a níveis dignos de subsistência, cujos recursos serão aplicados em ações suplementares de nutrição, habitação, educação, saúde, reforço de renda familiar e outros programas de relevante interesse social voltados para melhoria da qualidade de vida" (BRASIL, 2000b).

Indo ao encontro do disposto no documento final da Habitat II, o dispositivo instituiu um Fundo para angariar recursos voltados à promoção de direitos sociais e, consequentemente, melhorar a qualidade de vida do cidadão. E, conforme dispõe a Declaração de Istambul:

Para melhorar a qualidade de vida dentro dos assentamentos humanos é necessário que combatamos a deterioração das condições que, na maioria dos casos e, sobretudo, nos países em desenvolvimento, tornaram proporções de crise. Com esse objetivo, nós devemos abordar amplamente, interalia, os padrões de produção e consumo insustentáveis, sobretudo nos países industrializados; mudanças populacionais insustentáveis, incluindo alterações na sua estrutura e distribuição, com consideração prioritária a tendência a uma concentração excessiva; população sem-teto; aumento da pobreza; desemprego; exclusão social; instabilidade familiar; recursos inadequados; falta de infraestrutura, de serviços básicos e de planejamento adequado; insegurança e violência crescentes; degradação ambiental e aumento da vulnerabilidade a desastres (ONU, 1996).

Dessa forma, quanto mais recursos fossem destinados a programas sociais de saúde, educação e habitação, maior seriam as chances de enfrentamento das mazelas sociais e promoção do bem-estar social.

\section{Lei $\mathrm{n} .10 .150 / 00$}

Publicada no Diário Oficial de 22 de dezembro de 2000, a lei foi precedida por 54 medidas provisórias. Sua trajetória iniciou-se em 1996, com a edição da MPV n. 1.520, em 24 de setembro daquele ano, que determinava que:

As dívidas do Fundo de Compensação de Variações Salariais - FCVS, junto às instituições financiadoras, relativas a saldos devedores remanescentes da liquidação de contratos de financiamento habitacional, firmados com mutuários finais do Sistema Financeiro da Habitação - SFH, poderão ser objeto de novação, a ser celebrada entre cada credor e a União, nos termos desta Medida Provisória (BRASIL, 1996b, p. 04015).

Reeditada 14 vezes, a MPV n. 1.520-15, de 04 de dezembro de 1997, foi revogada e reeditada pela MPV n. 1.635-16, de 12 de dezembro de 1997, que trouxe pequenas alterações a respeito do FCVS

10 Apesar de previsto na Constituição Federal (art. 153, VII), o imposto sobre grandes fortunas não foi regulamentado até a presente data. 
e foi reeditada 6 vezes, até que a MPV n. 1.635-22, de 10 de junho de 1998, fosse revogada e reeditada pela MPV n. 1.696-23, de 30 de junho de 1998. As alterações foram mínimas, porém as reedições foram diversas e a MPV n. 1.696-28 foi reeditada em 14 de dezembro de 1998 pela MPV n. 1.768-29. Seguindo o mesmo padrão de poucas alterações e muitas reedições, a MPV n. 1.768-35 foi revogada e reeditada em 29 de junho de 1999 pela MPV n. 1.877-36 e a MPV n. 1.877-41 foi revogada e reeditada pela MPV n. 1.981-42, de 10 de dezembro de 1999. Por fim, a MPV n. 1.981-54, de 23 de novembro de 2000, transformou-se na Lei 10.150/00.

Essa lei permite que "as dívidas do FCVS, junto às instituições financiadoras, relativas a saldos devedores remanescentes da liquidação de contratos de financiamento habitacional, firmados com mutuários finais do SFH, poderão ser objeto de novação, a ser celebrada entre cada credor e a União" (BRASIL, 2000c).

Ao permitir a novação da dívida, a lei facilita o cumprimento da obrigação pelo FCVS, sem ameaçar os contratos entre o Fundo e os beneficiários do SFH. Portanto, a lei indiretamente garante o direito à moradia, mas diretamente não reflete princípios da Declaração de Istambul.

\section{Lei $\mathrm{n} .10 .188 / 01$}

Publicada no Diário Oficial de 14 de fevereiro de 2001, a Lei 10.188/01 foi precedida por 25 MPVs, começando pela MPV n. 1.823/99 e passando pelas MPVs n. 1.864/99 e n. 1.944/99, até que a MPV n. 2.135-24 foi convertida na Lei 10.188, em 12 de fevereiro de 2001.

A norma criou o Programa de Arrendamento Residencial (PAR), que consistia em um arrendamento residencial, com opção de compra, voltado exclusivamente à população de baixa renda. Para tanto, seria criado um Fundo, pela CEF, com saldos remanescentes do Fundo de Apoio ao Desenvolvimento Social (FAS), Fundo de Investimento Social (FINSOCIAL), Programa de Difusão Tecnológica para Construção de Habitação de Baixo Custo (PROTECH), Fundo de Desenvolvimento Social (FDS), além de créditos obtidos junto ao FGTS (BRASIL, 2001a).

Por meio desse Programa, a CEF constrói ${ }^{11}$ unidades habitacionais, que são arrendadas à população de baixa renda (BRASIL, 2001a). Como a compra do imóvel pelo beneficiário não é obrigatória ao final do contrato (CAIXA, 2017), ao arrendar o imóvel, o beneficiário não contrai uma dívida, mas obtém um local adequado para morar. Com isso, reduz-se o déficit habitacional, promovendo, assim, o direito à moradia para as classes mais baixas da população. A Lei, portanto, vai ao encontro da Declaração de Istambul e, mais especificamente, da Declaração de Vancouver, que estabelece prioridade no atendimento às necessidades da população mais pobre.

${ }^{11}$ A CEF compra o terreno e uma construtora é responsável pela construção dos imóveis. 
10. Lei $\mathrm{n} .10 .257 / 01$

Publicada no Diário Oficial de 11 de julho de 2001, a Lei 10.257/01, denominada Estatuto da Cidade, regulamentou os artigos 182 e 183 da CF, estabelecendo "normas de ordem pública e interesse social que regulam o uso da propriedade urbana em prol do bem coletivo, da segurança e do bem-estar dos cidadãos, bem como do equilíbrio ambiental” (BRASIL, 2001b).

Como bem destaca Bassul (2011), houve uma grande discussão no Parlamento a respeito da matéria de relevante interesse social, antes da aprovação, por unanimidade, do Estatuto da Cidade, que foi sancionado pelo então Presidente da República Fernando Henrique Cardoso, com alguns vetos:

Oriundos de vários partidos, dezesseis projetos foram formulados. Com maior ou menor abrangência (apenas cinco abordaram a questão como lei de caráter geral), as propostas tinham razoável campo de convergência e denotavam a importância social que a temática urbana passou a ensejar.

Entre os dezesseis projetos apresentados, ganhou evidência o Projeto de Lei do Senado no 181, de 1989, autodenominado "Estatuto da Cidade", de autoria do senador Pompeu de Souza, falecido em 1991. Após doze anos de tramitação que de um lado frustraram muitas expectativas, mas de outro aprimoraram o projeto -, a proposta foi aprovada por unanimidade (BASSUL, 2011, p. 11).

Mais importante norma brasileira sobre planejamento urbano, o Estatuto da Cidade serviu de exemplo para diversos países, ao traçar como objetivo da política urbana "o pleno desenvolvimento das funções sociais da cidade e da propriedade urbana, mediante as seguintes diretrizes gerais":

I - garantia do direito a cidades sustentáveis, entendido como o direito à terra urbana, à moradia, ao saneamento ambiental, à infraestrutura urbana, ao transporte e aos serviços públicos, ao trabalho e ao lazer, para as presentes e futuras gerações;

II - gestão democrática por meio da participação da população e de associações representativas dos vários segmentos da comunidade na formulação, execução e acompanhamento de planos, programas e projetos de desenvolvimento urbano;

III - cooperação entre os governos, a iniciativa privada e os demais setores da sociedade no processo de urbanização, em atendimento ao interesse social;

IV - planejamento do desenvolvimento das cidades, da distribuição espacial da população e das atividades econômicas do Município e do território sob sua área de influência, de modo a evitar e corrigir as distorções do crescimento urbano e seus efeitos negativos sobre o meio ambiente;

$\mathrm{V}$ - oferta de equipamentos urbanos e comunitários, transporte e serviços públicos adequados aos interesses $e$ necessidades da população e às características locais;

$\mathrm{VI}$ - ordenação e controle do uso do solo, de forma a evitar: a) a utilização inadequada dos imóveis urbanos; b) a proximidade de usos incompatíveis ou inconvenientes; c) o parcelamento do solo, a edificação ou o uso excessivos ou inadequados em relação à infraestrutura urbana; d) a instalação de empreendimentos ou atividades que possam funcionar como polos geradores de 
tráfego, sem a previsão da infraestrutura correspondente; e) a retenção especulativa de imóvel urbano, que resulte na sua subutilização ou não utilização; f) a deterioração das áreas urbanizadas; g) a poluição e a degradação ambiental;

VII - integração e complementaridade entre as atividades urbanas e rurais, tendo em vista o desenvolvimento socioeconômico do Município e do território sob sua área de influência;

VIII - adoção de padrões de produção e consumo de bens e serviços e de expansão urbana compatíveis com os limites da sustentabilidade ambiental, social e econômica do Município e do território sob sua área de influência;

IX - justa distribuição dos benefícios e ônus decorrentes do processo de urbanização;

$[\ldots]$

XII - proteção, preservação e recuperação do meio ambiente natural e construído, do patrimônio cultural, histórico, artístico, paisagístico e arqueológico;

XIII - audiência do Poder Público municipal e da população interessada nos processos de implantação de empreendimentos ou atividades com efeitos potencialmente negativos sobre o meio ambiente natural ou construído, o conforto ou a segurança da população;

XIV - regularização fundiária e urbanização de áreas ocupadas por população de baixa renda mediante o estabelecimento de normas especiais de urbanização, uso e ocupação do solo e edificação, consideradas a situação socioeconômica da população e as normas ambientais;

XV - simplificação da legislação de parcelamento, uso e ocupação do solo e das normas edilícias, com vistas a permitir a redução dos custos e o aumento da oferta dos lotes e unidades habitacionais. (BRASIL, 2001b). - grifo nosso

Visando promover justiça social e ambiental, além de inaugurar uma nova ordem urbanística, o Estatuto da Cidade refletiu quase que completamente o disposto na Declaração de Istambul, tratando de "buscar a sustentabilidade das cidades brasileiras, que precisam crescer economicamente sem deixar de preservar o meio ambiente nem tratar de forma injusta seus habitantes" (SANTIN, PEDRINI, COMIRAN, 2017, p. 566).

Importante ressaltar que, dentre os instrumentos de política urbana introduzidos por essa Lei, destaca-se o Plano Diretor, "o instrumento básico da política de desenvolvimento e expansão urbana" (BRASIL, 2001b) dos Municípios. Ou seja, é a Lei que estabelece as diretrizes a serem seguidas pelos administradores para o desenvolvimento das cidades, garantindo "o planejamento da atuação do Poder Público, possibilitando a gestão ordenada das cidades e aliando a atuação do Poder Público e a participação da sociedade civil no direcionamento das ações estatais e na consecução do bem-estar dos indivíduos" (REIS e VENÂNCIO, 2016, p.1207).

O Plano Diretor é obrigatório ${ }^{12}$ para cidades: i) com mais de vinte mil habitantes; ii) integrantes de regiões metropolitanas e aglomerações urbanas; iii) onde o Poder Público municipal pretenda utilizar

\footnotetext{
12 Nos termos do artigo 41 do Estatuto da Cidade.
} 
os instrumentos previstos no $\S 40$ do art. 182 da Constituição Federal ${ }^{13}$; iv) integrantes de áreas de especial interesse turístico; v) inseridas na área de influência de empreendimentos ou atividades com significativo impacto ambiental de âmbito regional ou nacional; vi $)^{14}$ incluídas no cadastro nacional de Municípios com áreas suscetíveis à ocorrência de deslizamentos de grande impacto, inundações bruscas ou processos geológicos ou hidrológicos correlatos (BRASIL, 2001b).

Importante ressaltar que, por expressa disposição legal, o Prefeito Municipal incorrerá em improbidade administrativa se deixar de tomar as providências necessárias para garantir que a lei que instituir o Plano Diretor seja revista, pelo menos, a cada dez $\operatorname{anos}^{15}$, bem como se não permitir a participação popular na elaboração do $\operatorname{Plano}^{16}$, visto que o Estatuto da Cidade introduziu a gestão democrática participativa, garantindo ao cidadão o direito de participar do planejamento urbano de sua cidade (BRASIL, 2001b). E, como destaca Mencio (2006, p. 29), "a participação popular é um princípio17 dotado de força normativa, que vincula o processo de planejamento municipal, em especial, o Plano Diretor".

Especificamente sobre direito à moradia, a Lei 10.257/01 incumbiu à União, isoladamente ou em conjunto com outro(s) ente(s) federado(s), o dever de instituir programas de construção de moradias e a melhoria das condições habitacionais ${ }^{18}$, tornou possível a contratação coletiva da concessão de direito real de uso de imóveis públicos nos casos de programas e projetos habitacionais de interesse social ${ }^{19}$, reforçou os requisitos para aquisição da propriedade por usucapião ${ }^{20}$ e introduziu a usucapião coletiva

\footnotetext{
${ }^{13}$ Art. 182. A política de desenvolvimento urbano, executada pelo Poder Público municipal, conforme diretrizes gerais fixadas em lei, tem por objetivo ordenar o pleno desenvolvimento das funções sociais da cidade e garantir o bem-estar de seus habitantes.

$\S 4$ ㅇ É facultado ao Poder Público municipal, mediante lei específica para área incluída no plano diretor, exigir, nos termos da lei federal, do proprietário do solo urbano não edificado, subutilizado ou não utilizado, que promova seu adequado aproveitamento, sob pena, sucessivamente, de: I - parcelamento ou edificação compulsórios; II imposto sobre a propriedade predial e territorial urbana progressivo no tempo; III - desapropriação com pagamento mediante títulos da dívida pública de emissão previamente aprovada pelo Senado Federal, com prazo de resgate de até dez anos, em parcelas anuais, iguais e sucessivas, assegurados o valor real da indenização e os juros legais (BRASIL, 1988e).

${ }^{14}$ Incluído pela Lei n. 12.608, de 10 de abril de 2012.

15 Nos termos do artigo 52, VII, do Estatuto da Cidade.

16 Nos termos do artigo 52, VI, do Estatuto da Cidade.

17 Barroso (2020, p. 649) ensina que "Princípios têm sentido e alcance mínimos, um núcleo essencial, no qual se equiparam às regras. A partir de determinado ponto, no entanto, ingressa-se em um espaço de indeterminação, no qual a demarcação de seu conteúdo estará sujeita à concepção ideológica ou filosófica do intérprete. Essa característica dos princípios, aliás, é que permite que a norma se adapte, ao longo do tempo, a diferentes realidades, além de permitir a realização da vontade da maioria, inerente ao regime democrático. Há, portanto, um sentido mínimo, oponível a qualquer grupo que venha a exercer o poder, e também um espaço cujo conteúdo será preenchido pela deliberação democrática.".

${ }^{18}$ Nos termos do artigo 30, III, do Estatuto da Cidade.

${ }^{19}$ Nos termos do artigo 40, $\S 2^{\circ}$, do Estatuto da Cidade.

${ }^{20}$ Nos termos do artigo 9o do Estatuto da Cidade.
} 
para população de baixa renda ${ }^{21}$, além de garantir o direito de preempção para o Poder Público executar programas e projetos habitacionais de interesse social ${ }^{22}$ (BRASIL, 2001b).

A Lei 10.257/01, portanto, vai totalmente ao encontro da Declaração de Istambul, porém, Moreira e Castro (2020, p. 533) ressaltam que "há falhas no que se refere à aplicação eficaz desses mecanismos viabilizados pelo documento (Estatuto da Cidade)".

\section{Medida Provisória n. 2.197/01}

Publicada no Diário Oficial de 27 de agosto de 2001, a Medida Provisória n. 2.197/01 trata de contratos de financiamento no âmbito do SFH. Iniciada em 1998 com a MPV n. 1.671, a norma foi reeditada 44 vezes sob os números 1.691//98, 1.762/98, 1.876/99, 1.951/99 e 2.075/00.

Além de permitir que contratos de financiamento sejam reajustados por planos diferentes dos previstos na Lei n. 8.692/93, a MPV instituiu outras medidas para facilitar o cumprimento do contrato de financiamento pelos beneficiários, tais como, limitação da taxa de juros dos financiamentos e redução do valor das prestações de acordo com a renda familiar do beneficiário (BRASIL, 2001e).

Apesar de ser uma norma benéfica aos beneficiários do SFH, pois essas medidas facilitam o cumprimento integral das obrigações, a norma não reflete princípios da Declaração de Istambul.

\section{Medida Provisória n. 2.212/01}

Publicada no Diário Oficial de 31 de agosto de 2001, a Medida Provisória n. 2.212/01 criou o Programa de Subsídio à Habitação de Interesse Social (PSH), que tinha por objetivo "tornar acessível a moradia para os segmentos populacionais de renda familiar alcançados pelos programas de financiamentos habitacionais de interesse social" (BRASIL, 2001f). Ao destinar recursos para programas habitacionais de interesse social, a norma busca a promoção do direito à moradia, refletindo, assim, princípios da Declaração de Istambul.

\section{Medida Provisória n. 2.218/01}

Publicada no Diário Oficial de 05 de setembro de 2001, a Medida Provisória n. 2.218/01 dispõe sobre a remuneração dos militares do Distrito Federal, garantindo a eles, dentre outros benefícios, o

\footnotetext{
${ }^{21}$ Nos termos do artigo 10 do Estatuto da Cidade.

${ }^{22}$ Nos termos do artigo 26, II, do Estatuto da Cidade.
} 
auxílio-moradia, um "direito pecuniário mensal devido ao militar, na ativa e na inatividade, para auxiliar nas despesas com habitação para si e seus dependentes" (BRASIL, 2001g).

Esse auxílio concedido aos militares fortalece a classe financeiramente para que busquem a garantia de seu direito à moradia, portanto, reflete uma das metas da Habitat II.

\section{Decreto n. $4.156 / 02^{23}$}

Publicado no Diário Oficial de 12 de março de 2002, o Decreto n. 4.156/02 regulamentou o PSH, estabelecendo a faixa salarial dos beneficiados e o valor total do imóvel e do financiamento (BRASIL, 2002a). O Decreto se coaduna à Habitat II, ao buscar uma distribuição justa de recursos, entre as unidades federativas, para enfrentar o déficit habitacional.

\section{Decreto n. $4.229 / 02^{24}$}

Publicado no Diário Oficial de 14 de maio de 2002, o Decreto n. 4.229/02 remodelou o Programa Nacional de Direitos Humanos (PNDH), traçando novos objetivos e passando a responsabilidade da execução para a Secretaria de Estado dos Direitos Humanos do Ministério da Justiça (BRASIL, 2002b). Apesar de o Decreto não mencionar moradia/habitação, ele trata de direitos humanos, que englobam direitos civis, políticos, sociais, culturais e econômicos, portanto, trata de direito à moradia.

O PNDH traça um roteiro para a promoção dos direitos humanos e redução das desigualdades, primeiramente identificando os problemas, para, posteriormente, difundir conceitos (conscientização da população) e implementar as ações (BRASIL, 2002b). Apesar de o Decreto não estabelecer as ações, a norma reflete princípios expressos no documento final da Habitat II, que vai além do direito à moradia, ao buscar a promoção dos direitos sociais como um todo.

\section{Decreto n. $4.494 / 02^{25}$}

Publicado no Diário Oficial de 04 de dezembro de 2002, o Decreto n. 4.494/02 regulamentou o IOF, mantendo a isenção prevista no Decreto-Lei n. $2.407 / 88$, relativa a operações de crédito para "fins habitacionais, inclusive a destinada à infraestrutura e saneamento básico relativos a programas ou

\footnotetext{
${ }^{23}$ Revogado pelo Decreto n. 5.247, de 19 de outubro de 2004.

${ }^{24}$ Revogado pelo Decreto n. 7.037, de 21 de dezembro de 2009.

${ }^{25}$ Revogado pelo Decreto n. 6.306, de 14 de dezembro de 2007.
} 
projetos que tenham a mesma finalidade" (BRASIL, 2002c) e reduzindo a zero a alíquota do seguro obrigatório vinculado a financiamento no âmbito do SFH.

Essas disposições facilitaram tanto a construção de novas moradias, quanto a implementação de infraestrutura básica a moradias, prezando, assim, pela qualidade de vida da população, um dos pilares da Habitat II.

\section{Decreto n. $4.675 / 03$}

Publicado no Diário Oficial de 17 de abril de 2003, o Decreto n. 4.675/03 regulamentou o Programa Nacional de Acesso à Alimentação, conhecido como Cartão-Alimentação, que tinha como principal objetivo garantir aos necessitados o acesso à alimentação. 0 combate à falta de alimentação veio acompanhado de ações educativas e estruturais, dentre elas, a construção ou reforma da habitação ${ }^{26}$ e obras de infraestrutura ${ }^{27}$ (BRASIL, 2003a).

A norma, portanto, buscou promover diversos direitos sociais, como saúde, alimentação, educação e moradia, estando em consonância com o disposto na Declaração de Vancouver, a respeito da melhoria da qualidade de vida do ser humano.

\section{Lei n. $10.741 / 03$}

Publicada no Diário Oficial de 03 de outubro de 2003, a Lei n. 10.741/03 instituiu o Estatuto do Idoso, que dedicou um capítulo inteiro ao tema habitação. Além de ressaltar que a habitação é um direito do idoso (BRASIL, 2003b), estabeleceu algumas diretrizes a serem seguidas, para satisfação das necessidades desses. Embora a Declaração de Istambul não mencione os idosos, ela ressalta a necessidade de igualdade entre as pessoas e a acessibilidade de todos aos equipamentos urbanos, o que o Estatuto do Idoso propõe.

\section{Lei $\mathrm{n} .10 .840 / 04$}

Publicada no Diário Oficial de 12 de fevereiro de 2004, a Lei n. 10.840/04, originada na MPV n. 133/03, criou o Programa Especial de Habitação Popular (PEHP), que tinha por objetivo oferecer moradia adequada para a população com renda de até 3 (três) salários-mínimos (BRASIL, 2004a). 0 Programa visava não apenas o auxílio para a aquisição de unidades habitacionais, mas também para a produção dessa, com auxílio à aquisição de lotes urbanizados e material de construção, além de permitir

\footnotetext{
${ }^{26}$ Nos termos do artigo 70, II, $f$, do Decreto n. 4.675/03.

${ }^{27}$ Nos termos do artigo 70, II, $d$ e $e$, do Decreto n. 4.675/03.
} 
a destinação de recursos para a adequação das moradias, por meio da urbanização de assentamentos e da requalificação urbana ${ }^{28}$ (BRASIL, 2004a).

A Lei garantiu, ainda, a participação popular no controle dos recursos do Programa ${ }^{29}$ e permitiu aos municípios isentar as unidades habitacionais resultantes do PEHP do pagamento da outorga onerosa do direito de construir ${ }^{30}$ (BRASIL, 2004a).

A Lei, portanto, criou um Programa para promover o direito à moradia adequada à população de baixa renda, preocupando-se não somente com a moradia em si, mas com o seu entorno, conforme proposto pela Habitat II.

\section{Lei n. $10.998 / 04$}

Publicada no Diário Oficial de 16 de dezembro de 2004, a Lei n. 10.998/04, originada na MPV n. 200, de 20 de julho 2004, alterou o PSH, estendendo a agentes financeiros do SFH as operações de financiamento do programa e definindo conceitos como financiamento e parcelamento (BRASIL, 2004d). Assim como a norma que instituiu o PSH, essa lei se coaduna à Habitat II, ao destinar recursos a programas habitacionais de interesse social, combatendo, assim, o déficit habitacional.

\section{Lei n. 11.124/05}

Publicada no Diário Oficial de 17 de junho de 2005, a Lei n. 11.124/05 criou o Sistema Nacional de Habitação de Interesse Social (SNHIS), que centralizou todos os programas e projetos governamentais voltados à habitação de interesse social, com vistas a viabilizar o acesso à terra urbanizada e à habitação digna e sustentável para a população de baixa renda (BRASIL, 2005b). Dentre os princípios $^{31}$ do SNHIS, destacam-se a moradia digna, a inclusão social; a democratização, a transparência dos procedimentos decisórios e a função social da propriedade urbana (BRASIL, 2005b), que também estão presentes na Declaração de Istambul.

Também em consonância com a Habitat II, estão algumas diretrizes ${ }^{32}$, como sustentabilidade econômica, financeira e social dos programas e projetos", estabelecimento de mecanismos de quotas para idosos, deficientes e famílias chefiadas por mulheres dentre o grupo identificado como o de menor

\footnotetext{
${ }^{28}$ Nos termos do artigo 10, § 10, da Lei n. 10.840/04.

${ }^{29}$ Nos termos do artigo 70 da Lei n. 10.840/04.

${ }^{30}$ Nos termos do artigo 80 da Lei n. 10.840/04.

${ }^{31}$ Nos termos do artigo 40, I, da Lei n. 11.124/05.

${ }^{32}$ Nos termos do artigo 4으, II, da Lei n. 11.124/05.
} 
renda e incentivo à pesquisa, incorporação de desenvolvimento tecnológico e de formas alternativas de produção habitacional (BRASIL, 2005b).

A Lei criou, ainda, o Fundo Nacional de Habitação de Interesse Social (FNHIS) para centralizar os recursos do SNHIS, recursos esses que poderiam ser aplicados na construção, aquisição ou reforma de moradias, bem como implementação de infraestrutura adequada (BRASIL, 2005b).

Por fim, a lei esclareceu que os benefícios oferecidos pelo SHNIS não estariam restritos a concessão de recursos, mas poderiam ser redução ou isenção de impostos ou qualquer outro benefício que reduzisse os custos com a habitação e a infraestrutura do entorno (BRASIL, 2005b).

A Lei n. 11.124/05, portanto, vai ao encontro do disposto no documento final da Habitat II.

\section{Lei $\mathrm{n} .11 .308 / 06^{33}$}

Publicada no Diário Oficial de 24 de maio de 2006, a Lei n. 11.308/06 abriu um crédito extraordinário, em favor do Ministério das Cidades, para aplicação em projetos habitacionais de interesse social, urbanização e regularização fundiária (BRASIL, 2006a). Aumentando os recursos a serem destinados a esses projetos, a Lei colabora com a promoção desses, indo, assim, ao encontro da Declaração de Istambul.

\section{Decreto n. $5.796 / 06$}

Publicada no Diário Oficial de 07 de junho de 2006, Decreto no 5.796, regulamenta a Lei n. 11.124/05, que criou o SNHIS e o FNHIS. Em relação à origem e à aplicação dos recursos do FNHIS, o Decreto manteve fielmente o disposto na Lei criadora. O Decreto apenas definiu a composição do Conselho Gestor do FNHIS, garantindo a participação popular, e aumentou as atribuições da CEF, a agente operadora do Fundo (BRASIL, 2006b).

\section{Lei $n .11 .324 / 06$}

Publicada no Diário Oficial de 20 de julho de 2006, a Lei n. 11.324/06, resultado da conversão da MPV n. 284, de 06 de março de 2006, alterou, dentre outros, a Lei n. 5.859/72, tornando proibido o desconto pelo empregador doméstico de com alimentação, vestuário, higiene ou moradia do empregado, salvo se a moradia for em local diverso da residência onde os serviços são prestados (BRASIL, 2006c).

\footnotetext{
${ }^{33}$ Conversão da MPV n. 279, de 7 de fevereiro de 2006.
} 
Essa norma, no entanto, não tem impacto direto sobre o direito à moradia, tampouco reflete princípios da Habitat II.

\section{Lei n. 11.355/06}

Publicada no Diário Oficial de 20 de outubro de 2006, a Lei n. 11.355/06, resultante da conversão da MPV n. 301/06, dentre outras disposições, tratou da concessão de auxílio-moradia a servidores públicos que exercem a função em Município distinto do de seu domicílio (BRASIL, 2006e). Esse auxílio, porém, não busca a redução do déficit habitacional, mas tão somente gratificar o servidor que trabalha em outro Município. A norma, portanto, em nada reflete a Declaração de Istambul.

\section{Decreto de 25 de outubro de 2006}

O Decreto criou um Grupo de Trabalho Interministerial (GTI) "com a finalidade de elaborar estudos e apresentar propostas de políticas públicas para a inclusão social da população em situação de rua" (BRASIL, 2006f).

Apesar de o grupo ter sido criado por tempo limitado, foi uma importante iniciativa, pois o índice de moradores de rua no Brasil é elevado, o que demonstra claramente o déficit habitacional do país. E realizar estudos para implementar políticas públicas voltadas a essa população significa combater o déficit habitacional, promovendo moradias para quem não tem.

A norma reflete um dos principais pilares da Habitat II: a inclusão.

\section{Decreto n. $6.025 / 07$}

Publicado no Diário Oficial de 22 de janeiro de 2007, o Decreto n. 6.025/07 criou o Programa de Aceleração do Crescimento (PAC), um plano estratégico para investimentos em infraestrutura social, urbana, logística e energética do Brasil (PAC, 2017):

Representa um novo modelo de planejamento, gestão e execução do investimento público. Articula projetos de infraestrutura públicos e privados e medidas institucionais para aumentar o ritmo de crescimento da economia. Modernizar a infraestrutura, melhorar o ambiente de negócios, estimular o crédito e o financiamento, aperfeiçoar a gestão pública e elevar a qualidade de vida da população são alguns dos objetivos do PAC. É também um instrumento de inclusão social e de redução das desigualdades regionais. Suas ações e obras geram empregos que garantem renda e consumo para milhares de trabalhadores e suas famílias (BRASIL, 2015). 
O PAC, portanto, foi um Programa criado em consonância com a Habitat II, pois previa investimentos em infraestrutura, para melhoria dos assentamentos humanos, além de buscar a redução das desigualdades sociais.

\section{Lei n. 11.481/07}

Publicada no Diário Oficial de 31 de maio de 2007, a Lei n. 11.481/07 foi resultado da conversão da MPV n. 335/06, que foi precedida pela MPV n. 292/06, e alterou diversos dispositivos de outras normas.

Primeiramente, alterou a Lei n. 9.636/98, para autorizar o Poder Público a regularizar assentamentos humanos, inclusive realizando convênios com parcerias privadas, além de permitir a regularização do assentamento humano ocupado por população de baixa renda, sem necessidade de individualização da posse. A lei isentou, ainda, os ocupantes de assentamentos informais localizados em zonas de especial de interesse social de comprovarem o efetivo aproveitamento do imóvel (BRASIL, 2007b).

Em relação à regularização fundiária de interesse social, a Lei definiu que se a área tiver essa destinação previamente, será vedada a inscrição da ocupação, bem como se a ocupação comprometer a "integridade das áreas de uso comum do povo, de segurança nacional ou de preservação ambiental" (BRASIL, 2007b). Além disso, dispensou de licitação a cessão de bens imóveis da União, permitiu a cessão gratuita de direitos enfitêuticos e autorizou a doação de bens imóveis de domínio da União para realização dessa (BRASIL, 2007b).

A Lei também facilitou a venda do domínio pleno de imóveis da União para projetos de caráter social para fins de moradia e autorizou a concessão de uso especial de áreas da União para fins de moradia (BRASIL, 2007b).

A Lei alterou o Decreto-Lei n. 9.760, de 05 de setembro de 1946, para instituir a demarcação de terrenos para regularização fundiária de interesse social, destinada a famílias com renda mensal de até 5 (cinco) salários-mínimos; o Decreto-Lei n. 1.876, de 15 de julho de 1981, para isentar as empresas públicas, as sociedades de economia mista e os fundos públicos do pagamento de laudêmio nas transferências de bens imóveis dominiais pertencentes à União e destinados à realização de programas habitacionais ou de regularização fundiária de interesse social; o Código Civil, para determinar que a concessão de uso especial para fins de moradia é um direito real; e a Lei de Registros Públicos, para facilitar a averbação e o registro dos imóveis oriundos de regularização fundiária (BRASIL, 2007b).

Essa Lei reflete diversos princípios da Declaração de Istambul, principalmente no que se refere à população de baixa renda (um dos focos da Habitat II), que representa a maior parte do déficit 
habitacional. As novas regras instituídas por ela visam a facilitar a regularização fundiária e a implementação de programas habitacionais de interesse social, promovendo, assim, o direito à moradia para a população economicamente menos favorecida. A Lei destaca, ainda, um dos pilares da Habitat II: a sustentabilidade (ambiental, econômica e social).

\section{Lei $\mathrm{n} .11 .485 / 07$}

Publicada no Diário Oficial de 14 de junho de 2007, a Lei n. 11.485/07, resultado da conversão da MPV n. 347/07, autorizou a União a conceder um crédito para a CEF, ampliando, assim, os investimentos em saneamento popular e habitação social, combatendo, assim, o déficit habitacional e promovendo a melhoria dos assentamentos humanos, por meio da implementação de saneamento básico (BRASIL, 2007c), duas metas da Declaração de Istambul.

\section{Lei n. 11.490/07}

Publicada no Diário Oficial de 21 de junho de 2007, a Lei n. 11.490/07, resultante da Conversão da MPV n. 341/2006, estabeleceu o limite máximo do valor do auxílio-moradia concedido a servidores públicos que exercem a função em Município distinto do de seu domicílio (BRASIL, 2007d). Assim como a Lei n. 11.355/06, que instituiu esse auxílio, essa norma não busca a redução do déficit habitacional, mas tão somente gratificar o servidor que trabalha em outro Município. A norma, portanto, em nada reflete a Declaração de Istambul.

\section{Decreto n. $6.194 / 07$}

Publicado no Diário Oficial de 04 de julho de 2007, o Decreto n. 6.194/07 regulamenta o Regime Especial de Incentivos para o Desenvolvimento da Infraestrutura (REIDI), que isenta das Contribuições PIS/PASEP e COFINS a pessoa jurídica de direito privado que adquirir máquinas e objetos destinados a implantação de obras de infraestrutura nos setores de:

I - transportes, abrangendo rodovias, ferrovias, hidrovias, trens urbanos e portos organizados;

II - energia, abrangendo a geração e a transmissão de energia elétrica de origem hidráulica, eólica, nuclear, solar e térmica;

III - saneamento básico, abrangendo abastecimento de água potável e esgotamento sanitário;

IV - irrigação (BRASIL, 2007e). 
Ao facilitar a compra desses equipamentos, o Decreto incentiva a realização de obras de infraestrutura, como saneamento básico e transporte, além da irrigação do meio rural. E a melhoria das infraestruturas urbana e rural é um dos pilares da Habitat II.

\section{Decreto n. $6.215 / 07^{34}$}

Publicado no Diário Oficial de 28 de setembro de 2007, o Decreto n. 6.215/07 estabelece o Compromisso pela Inclusão das Pessoas com Deficiência. Dentre as diretrizes a serem seguidas, tanto pelo poder público, quanto pelos particulares, estão a ampliar do acesso a órteses e próteses e a acessibilidade de habitações, escolas, transporte e infraestrutura (BRASIL, 2007f).

A acessibilidade e a inclusão das pessoas com deficiência são princípios da Declaração de Istambul, estando a norma em consonância com ela.

\section{Decreto n. $6.276 / 07$}

Publicado no Diário Oficial de 29 de novembro de 2007, o Decreto n. 6.276/07 elencou os Programas de urbanização, habitação social, saneamento básico, melhoria habitacional e de assentamentos humanos, entre outros, que seriam beneficiadas pelo PAC, tornando obrigatório o repasse financeiro ao ente federado responsável pelo Programa (BRASIL, 2007h).

Esse Decreto materializou o PAC, que conforme ressaltado anteriormente, está em consonância com a Habitat II.

\section{Decreto n. $6.306 / 07$}

Publicado no Diário Oficial de 17 de dezembro de 2007, o Decreto n. 6.306/07 regulamentou o IOF, mantendo a isenção prevista no Decreto-Lei n. 2.407/88, relativa a operações de crédito para "fins habitacionais, inclusive a destinada à infraestrutura e saneamento básico relativos a programas ou projetos que tenham a mesma finalidade" (BRASIL, 2007i) e reduzindo a zero a alíquota do seguro obrigatório vinculado a financiamento no âmbito do SFH.

Essas disposições facilitaram tanto a construção de novas moradias, quanto a implementação de infraestrutura básica a moradias, prezando, assim, pela qualidade de vida da população, um dos pilares da Habitat II.

\footnotetext{
${ }^{34}$ Revogado pelo Decreto n. 7.612, de 17 de novembro de 2011.
} 


\section{Decreto n. 6.450/08}

Assim como o Decreto n. 6.276/07, materializou o PAC ao elencar os Programas de urbanização, habitação social, saneamento básico, melhoria habitacional e de assentamentos humanos, entre outros, que seriam beneficiadas pelo PAC, tornando obrigatório o repasse financeiro ao ente federado responsável pelo Programa (BRASIL, 2008a). E, assim como o Decreto retromencionado, está em consonância com a Habitat II.

\section{Lei n. 11.888/08}

Publicada no Diário Oficial de 26 de dezembro de 2008, a Lei n. 11.888/08 assegurou às famílias com renda de até 3 (três) salários-mínimos o direito à assistência técnica pública e gratuita para o projeto e a construção de habitação de interesse social para sua própria moradia (BRASIL, 2008b).

Além de expressamente promover o direito à moradia ${ }^{35}$, a Lei objetivava adequar a moradia e seu entorno, bem como evitar a ocupação de áreas de risco e de interesse ambiental ${ }^{36}$ (BRASIL, 2008b). A Lei, portanto, traz três pilares da Habitat II: facilitação da transferência de tecnologias e conhecimentos, promoção de moradias adequadas a todos e proteção ambiental.

\section{Lei n. 11.977/09}

Publicada no Diário Oficial de 08 de julho de 2009, a Lei n. 11.977/09, originada na MPV n. 459/09, criou o Programa Minha Casa Minha Vida (PMCMV), principal política habitacional brasileira em vigor, que começou unindo o Programa Nacional de Habitação Urbana (PNHU) e o Programa Nacional de Habitação Rural (PNHR) e hoje cria mecanismos de incentivo à produção e aquisição de novas unidades habitacionais pela população de baixa renda, bem como para requalificação ${ }^{37}$ de imóveis (BRASIL, 2009b).

Com investimentos na ordem de $\mathrm{R} \$ 34$ bilhões (sendo $\mathrm{R} \$ 25,5$ bilhões do Orçamento Geral da União, R\$ 7,5 bilhões do FGTS e R\$ 1 bilhão do BNDES), o Programa prevê a construção de um milhão de moradias no prazo de dois anos, além da promessa de geração de emprego, renda e sustentação econômica para um país temeroso da crise (ROMAGNOLI, 2012, p. 86).

\footnotetext{
${ }^{35}$ Nos termos do artigo $2^{\circ} \circ$, $§ 2^{\circ} \circ$, da Lei $11.888 / 08$.

${ }^{36}$ Nos termos do artigo 2으, $\S 22^{\circ}$, III, da Lei $11.888 / 08$.

${ }^{37}$ Nos termos do art. 1ㅇ, § 1ㅇ, IV, da Lei n. 11.977/09, é "aquisição de imóveis conjugada com a execução de obras e serviços voltados à recuperação e ocupação para fins habitacionais, admitida ainda a execução de obras e serviços necessários à modificação de uso" (BRASIL, 2009b).
} 
Para tanto, a União pode: a) conceder subvenção econômica ao beneficiário; b) participar do Fundo de Arrendamento Residencial (FAR), mediante integralização de cotas e transferência de recursos ao FDS; c) realizar oferta pública de recursos destinados à subvenção econômica ao beneficiário pessoa física; d) participar do FGHab; e) conceder subvenção econômica por meio do BNDES (BRASIL, 2009b).

Monteiro e Veras (2015, p. 1184) detalham a origem dos recursos:

A CEF é o agente operacional e financeiro do PMCMV que é gerido pelo Ministério das Cidades, utilizando recursos do Fundo de Desenvolvimento Social (FDS), Fundo de Garantia por Tempo de Serviço (FGTS), Fundo de Arrendamento Residencial (FAR), do Banco Nacional de Desenvolvimento Econômico e Social (BNDES) e do Fundo Garantidor da Habitação Popular (FGHab). Ele foi incluído no Programa de Aceleração do Crescimento 2 (PAC 2), em 2010, situado como um de seus eixos.

Considerando que o déficit habitacional é elevado e os recursos são limitados, a lei estabeleceu as prioridades ${ }^{38}$ de atendimento do Programa:

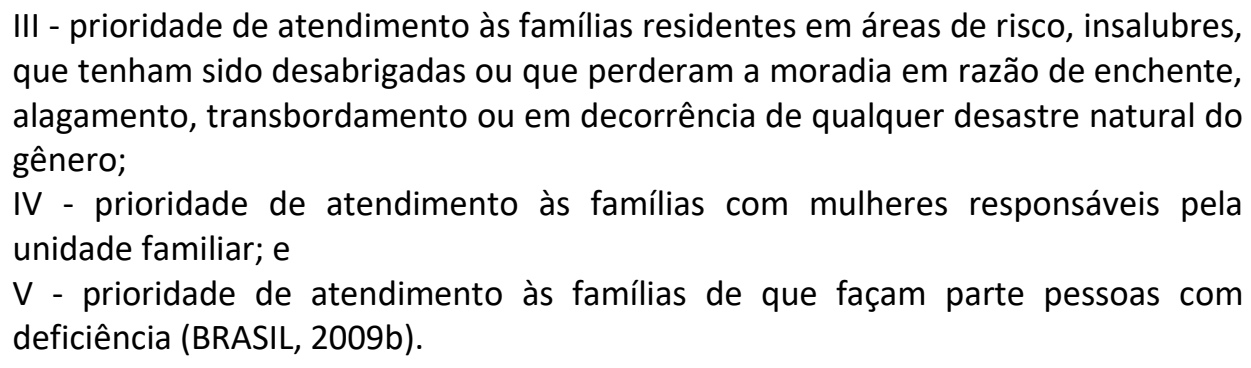

III - prioridade de atendimento às famílias residentes em áreas de risco, insalubres, que tenham sido desabrigadas ou que perderam a moradia em razão de enchente, alagamento, transbordamento ou em decorrência de qualquer desastre natural do gênero;

IV - prioridade de atendimento às famílias com mulheres responsáveis pela unidade familiar; e

$\mathrm{V}$ - prioridade de atendimento às famílias de que façam parte pessoas com deficiência (BRASIL, 2009b).

Também ficou definido que o Governo Federal dividiria os beneficiários em faixas, de acordo com a renda, para melhor atendimento destes, variando as porcentagens de juros e de subvenção econômica de acordo com a renda mensal familiar. Atualmente, os beneficiários são classificados em 4 faixas (CAIXA, 2017):

Faixa 1: famílias com rendimento mensal de até $\mathrm{R} \$ 1.800$;

Faixa 1,5: famílias com rendimento mensal de até $\mathrm{R} \$ 2.600$;

Faixa 2: famílias com rendimento mensal de até $\mathrm{R} \$ 4.000$;

Faixa 3: famílias com rendimento mensal de até $\mathrm{R} \$ 9.000$;

O Governo definiu, ainda, os tetos dos valores dos imóveis, de acordo com o Município, conforme quadro a seguir:

\footnotetext{
${ }^{38}$ Apesar de a Lei pré-definir os critérios de prioridade, permitiu que Estados, Municípios e DF estabelecessem outros critérios de seleção dos beneficiários, desde que previamente aprovados pelos conselhos de habitação, nos termos do artigo 3 ㅇ, § 4으, da Lei n. 11.977/09.
} 
QUADRO 1: Tetos dos valores dos imóveis do PMCMV

\begin{tabular}{|c|c|c|c|c|}
\hline \multicolumn{5}{|c|}{ NOVOS TETOS DO VALOR DOS IMÓVEIS } \\
\hline Recorte territorial & $\begin{array}{l}\text { DF, RJ } \\
\text { e SP }\end{array}$ & $\begin{array}{c}\text { Regiảo Sul, } \\
\text { ESe MG }\end{array}$ & $\begin{array}{l}\text { Regiāo Centro- } \\
\text { Oeste, exceto DF }\end{array}$ & $\begin{array}{c}\text { Regiōes Norte } \\
\text { e Nordeste }\end{array}$ \\
\hline Capitais estaduais classificadas pelo IBGE como metrópoles & RS $240 \mathrm{mil}$ & R\$ 215 mil & RS $190 \mathrm{mil}$ & RS $190 \mathrm{mil}$ \\
\hline $\begin{array}{l}\text { Demais capitais estaduais e municípios com populaçăo maior ou } \\
\text { igual a } 250 \text { mil habitantes classificados pelo IBGE como capitais } \\
\text { regionais; municípios com populaçáo maior ou igual a } 100 \text { mil } \\
\text { habitantes integrantes das regiōes metropolitanas das capitais } \\
\text { estaduais, de Campinas, da Baixada Santista e das regióes integradas } \\
\text { de desenvolvimento das capitais }\end{array}$ & $\mathrm{R} \$ 230 \mathrm{mil}$ & $\mathrm{R} \$ 190 \mathrm{mil}$ & RS 180 mil & RS $180 \mathrm{mil}$ \\
\hline $\begin{array}{l}\text { Municípios com populaçáo maior ou igual a } 100 \text { mil habitantes; } \\
\text { municipios com populaçáo menor que } 100 \text { mil habitantes } \\
\text { integrantes das regiōes metropolitanas das capitais estaduais, } \\
\text { de Campinas, da Baixada Santista e das regiōes integradas de } \\
\text { desenvolvimento das capitais; municipios com menos de } 250 \text { mil } \\
\text { habitantes classificados pelo IBGE como capitais regionais }\end{array}$ & RS 180 mil & R\$ $170 \mathrm{mil}$ & RS $165 \mathrm{mil}$ & RS $160 \mathrm{mil}$ \\
\hline $\begin{array}{l}\text { Municípios com populaçáo maior ou igual a } 50 \text { mil e menor que } 100 \\
\text { mil habitantes }\end{array}$ & RS $145 \mathrm{mil}$ & RS 140 mil & RS $135 \mathrm{mil}$ & RS $130 \mathrm{mil}$ \\
\hline Municípios com população com entre 20 mil e 50 mil habitantes & R\$ $110 \mathrm{mil}$ & RS $105 \mathrm{mil}$ & RS 105 mil & R\$ 100 mil \\
\hline Demais municipios & RS 95 mil & RS 95 mil & RS 95 mil & RS 95 mil \\
\hline
\end{tabular}

Fonte: CAIXA, 2017.

Segundo Romagnoli, o Programa se destaca no cenário nacional, pois "desde o BNH não havia o comprometimento do governo com a oferta de moradias que fizesse frente à realidade do déficit do país" (2012, p. 89).

Como bem explicam Monteiro e Veras (2015), o grande objetivo do PMCMV não é a venda e compra de imóveis prontos, mas o financiamento para a construção de imóveis novos, pois além de visar à redução do déficit habitacional, o Programa foi implementado como forma de superar a crise econômica então vigente no País, buscando aquecer a economia e gerar empregos com a construção civil. Porém, a lei prevê a possibilidade de requalificação de imóveis urbanos, o que, para os autores, seria uma melhor opção, visto que imóveis vazios normalmente já possuem a infraestrutura urbana necessária, gerando menos gastos ao Poder Público.

Considerando que as famílias que são alocadas nos empreendimentos do PMCMV sofrem grandes impactos em suas vidas, seja em razão do novo estilo de ocupação, seja em razão do novo local de moradia (muitas vezes distante do espaço de vida), a lei determinou que "os Estados, Municípios e Distrito Federal que aderirem ao PMCMV e a Caixa Econômica Federal serão responsáveis pela execução do trabalho técnico e social pós-ocupação dos empreendimentos implantados" (BRASIL, 2009b). Esse dispositivo se coaduna à Declaração de Istambul, ao se preocupar com a qualidade de vida dos seres humanos que ocuparão os empreendimentos.

Em relação aos imóveis urbanos, a Lei ${ }^{39}$ determinou que todos os empreendimentos do PMCMV deveriam estar dentro da malha urbana ou em área de expansão, de acordo com o Plano Diretor do

\footnotetext{
${ }^{39}$ Incluído pela Lei n. 12.424, de 16 de junho de 2011.
} 
Município, além de oferecer infraestrutura básica, como saneamento básico, iluminação e vias de acesso, bem como equipamentos públicos próximos (já instalados ou compromisso do Poder Público de instalar), relacionados a educação, saúde, lazer e transporte público (BRASIL, 2009b).

Outros requisitos estabelecidos pela Lei foram a adequação ambiental do projeto, condições de sustentabilidade das construções e uso de novas tecnologias construtivas (BRASIL, 2009b), indo, assim, ao encontro da sustentabilidade ambiental proposta pela Declaração de Istambul.

Já em relação à sustentabilidade social dos empreendimentos, a Lei determinou que em todos os empreendimentos do Programa fossem asseguradas condições de acessibilidade a todas as áreas públicas e de uso comum, além de unidades adaptáveis ao uso por pessoas com deficiência, pessoas com mobilidade reduzida e idosos (BRASIL, 2009b).

Em relação aos contratos de financiamento, a Lei determinou como um dos princípios o equilíbrio econômico-financeiro desses contratos, que seriam realizados pelas entidades integrantes do SFH, garantindo, assim, a sustentabilidade econômica dos empreendimentos, em consonância à Habitat II. Também buscando a sustentabilidade econômica dos beneficiários do Programa, estabeleceu-se a redução das custas e emolumentos cartorários relacionados aos empreendimentos do PMCMV (BRASIL, 2009b).

Já em relação aos imóveis rurais do PNHR, estabeleceu-se que os recursos do Programa seriam tanto para produção e reforma de imóveis para agricultores familiares e trabalhadores rurais, quanto para assistência técnica (BRASIL, 2009b).

Um ponto extremamente relevante do PMCMV é a proteção da moradia da família, prevista na Seção VII da Lei n. 11.977/09. Segundo seu artigo 35, "os contratos e registros efetivados no âmbito do PMCMV serão formalizados, preferencialmente, em nome da mulher" (BRASIL, 2009b), que também ficará com o título da propriedade em caso de separação, divórcio ou dissolução da união estável. E, apesar de parecer que a lei busca a proteção ou empoderamento da mulher, o parágrafo único deixa claro que a proteção é à família, pois nos casos de guarda exclusiva do pai "o título da propriedade do imóvel será registrado em seu nome ou a ele transferido"40 (BRASIL, 2009b). E essa proteção especial a crianças e jovens é um dos pilares da Habitat II.

\section{Decreto n. $7.053 / 09$}

Publicado no Diário Oficial de 24 de dezembro de 2009, o Decreto n. 7.053/09 instituiu a Política Nacional para a População em Situação de Rua, resultante do GTI criado pelo Decreto de 25 de outubro de 2006. Segundo o Decreto, considera-se população em situação de rua:

\footnotetext{
${ }^{40}$ Incluído pela Lei no 12.693, de 24 de julho de 2012.
} 
O grupo populacional heterogêneo que possui em comum a pobreza extrema, os vínculos familiares interrompidos ou fragilizados e a inexistência de moradia convencional regular, e que utiliza os logradouros públicos e as áreas degradadas como espaço de moradia e de sustento, de forma temporária ou permanente, bem como as unidades de acolhimento para pernoite temporário ou como moradia provisória (BRASIL, 2009d).

Dentre as diretrizes da Política estão a promoção dos direitos civis, políticos, econômicos, sociais (como moradia), culturais e ambientais; e a participação popular (BRASIL, 2009d), dois pilares da Habitat II. E, também em consonância com a Declaração de Vancouver, estão os princípios dessa política, como o respeito à dignidade humana e às diferenças entre as pessoas.

O Programa tinha por objetivos garantir o acesso dessa população a direitos básicos, como educação, saúde, moradia e trabalho, capacitar profissionais para atender essas pessoas, além de implantar centros de defesa dos direitos humanos e criar canais de comunicação para o recebimento de denúncias de violência contra a população em situação de rua (BRASIL, 2009d).

A Lei, portanto, buscava promover direitos à população em situação de rua, para garantir a inclusão dessas pessoas na sociedade, uma das metas presentes no documento final da Habitat II.

\section{Lei n. $12.249 / 10$}

Publicada no Diário Oficial de 14 de junho de 2010, a Lei n. 12.249/10 trouxe diversas alterações à lei do PMCMV, dentre as quais se destacam a concessão de subvenção econômica para facilitar a aquisição ou produção do imóvel residencial e a concessão de recursos do FGHab para "I - produção ou aquisição de imóveis novos em áreas urbanas; II - requalificação de imóveis já existentes em áreas consolidadas no âmbito do PNHU; e III - produção de moradia no âmbito do PNHR" (BRASIL, 2010b).

Ao facilitar a aquisição de imóveis por meio de subvenção econômica e destinação de recursos do Fundo, a lei buscou reduzir o déficit habitacional, uma das metas da Habitat II.

\section{Decreto n. $7.612 / 11$}

Publicada no Diário Oficial de 18 de novembro de 2011, o Decreto n. 7.612/11 instituiu o Plano Nacional dos Direitos da Pessoa com Deficiência, denominado Plano Viver sem Limite, que tinha por objetivo garantir acessibilidade aos locais públicos e privados, principalmente às moradias, e inclusão à educação, sociedade e mercado de trabalho das pessoas portadoras de deficiência (BRASIL, 2011c). Além de buscar promoção dos direitos dessas pessoas, a Lei buscou a inclusão delas na sociedade, por meio de políticas, programas e ações governamentais, conforme disposto na Declaração de Vancouver. 


\section{Lei $\mathrm{n} .13 .089 / 15$}

Publicada no Diário Oficial de 12 de janeiro de 2015, a Lei n. 13.089/15 instituiu o Estatuto da Metrópole, que "estabelece diretrizes gerais para o planejamento, a gestão e a execução das funções públicas de interesse comum em regiões metropolitanas ${ }^{41}$ e em aglomerações urbanas ${ }^{42 " ~(B R A S I L, ~}$ 2015a).

Apesar de a CF estabelecer a autonomia dos municípios ${ }^{43}$, algumas questões ultrapassam os limites municipais, sem, no entanto, serem consideradas de interesse estadual, como nos casos dos resíduos sólidos, recursos hídricos, mobilidade urbana (principalmente em razão da migração pendular), trabalho e moradia. Dessa forma, não cabe aos estados tratar a questão, mas aos municípios, que, diante da impossibilidade de invasão à esfera de outros municípios, não conseguem solucionar os problemas.

Por isso, foi promulgado o Estatuto da Metrópole, que regula tanto a instituição das Regiões Metropolitanas, quanto a governança interfederativa e os instrumentos de desenvolvimento urbano integrado (BRASIL, 2015a).

Em que pese a lei não trate especificamente de moradias, ela trata de questões relacionadas aos assentamentos humanos, como uso e ocupação do solo, estando ideologicamente de acordo com a Declaração de Istambul, que busca um tratamento global das questões relacionadas aos assentamentos humanos.

\section{CONSIDERAÇÕES FINAIS}

Conforme já destacado na parte I desse artigo, a Declaração de Istambul tratou do direito à moradia sob o tripé da sustentabilidade: ambiental, social e econômica.

Após a Habitat II, foram editadas no Brasil 64 normas contendo os termos 'moradia' e/ou 'habitação'. Dessas, 3 contêm os termos, mas não tratam de direito à moradia, e 20 tratam de questões administrativas e burocráticas, sem impacto direito no direito à moradia, conforme o Gráfico 1.

\footnotetext{
${ }^{41}$ Nos termos do artigo $2^{\circ}$, I, da Lei n. 13.089/15: "aglomeração urbana que configure uma metrópole (espaço urbano com continuidade territorial que, em razão de sua população e relevância política e socioeconômica, tem influência nacional ou sobre uma região que configure, no mínimo, a área de influência de uma capital regional, conforme os critérios adotados pela Fundação Instituto Brasileiro de Geografia e Estatística - IBGE)".

${ }^{42}$ Nos termos do artigo $2^{\circ}$, I, da Lei n. 13.089/15: "unidade territorial urbana constituída pelo agrupamento de 2 (dois) ou mais Municípios limítrofes, caracterizada por complementaridade funcional e integração das dinâmicas geográficas, ambientais, políticas e socioeconômicas".

${ }^{43}$ Nos termos do artigo 18 da Constituição Federal.
} 
Gráfico 1. Legislação federal brasileira entre 1996 e 2016

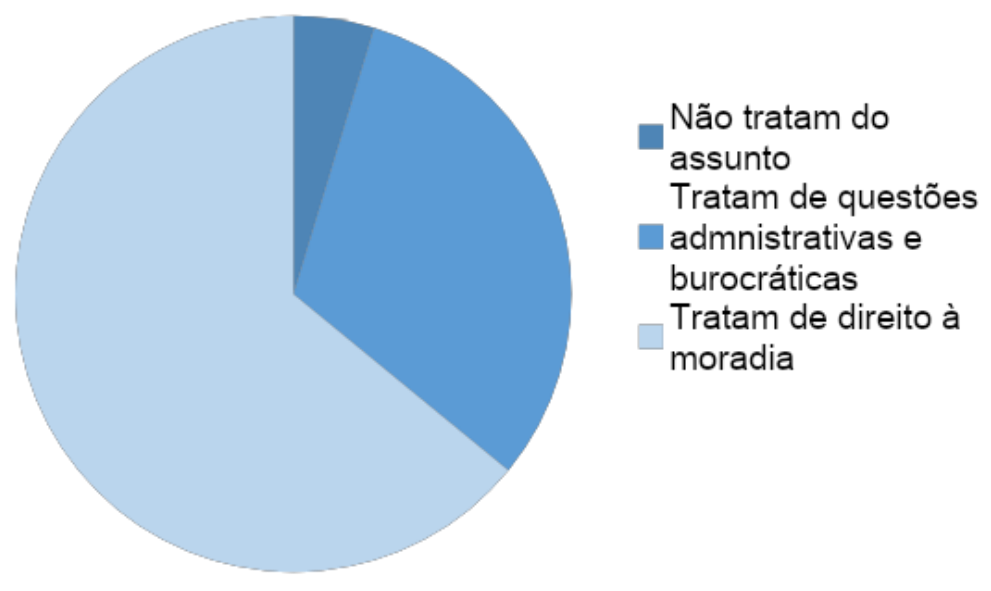

Dentre as 41 normas que tratam do direito à moradia, 34 refletem diretrizes da Declaração de Istambul (conforme Gráfico 2), ainda que sem referência expressa na exposição de motivos. $O$ impacto da Habitat II na legislação brasileira foi mais evidente, com a inclusão da moradia no rol dos direitos sociais previstos na Constituição federal, com a criação do Estatuto da Cidade, que em sua exposição de motivos fez referência direta à Conferência, e com a criação do Programa Minha Casa, Minha Vida, que é a política habitacional brasileira de maior impacto, porém ainda insuficiente, na promoção do direito à moradia.

Gráfico 2. Os reflexos da Declaração de Istambul na legislação federal brasileira entre 1996 e 2016

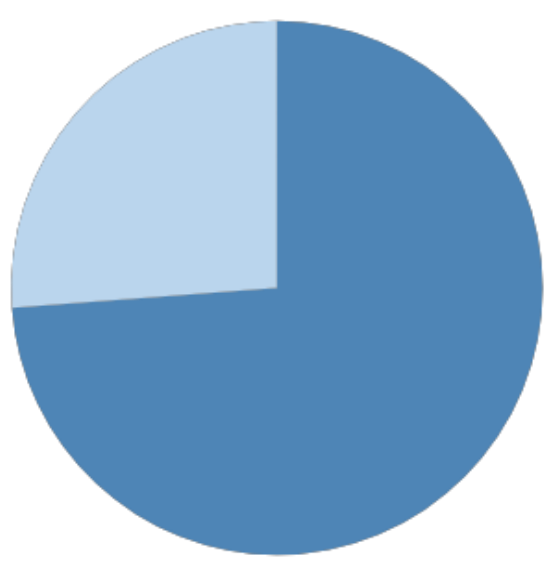

Refletem princípios

Não refletem princípios

A Habitat II, portanto, teve impactos diretos e indiretos na legislação federal brasileira, em especial na elaboração do Estatuto da Cidade, que estabelece normas gerais sobre planejamento urbano. A sustentabilidade dos assentamentos humanos, conforme proposto pela Habitat II, ainda não é 
a realidade do Brasil, sequer do ponto de vista positivo. Porém, a legislação sobre o assunto está se desenvolvendo e possui excelentes parâmetros internacionais para auxiliar nesse desenvolvimento.

\section{REFERÊNCIAS}

ARRUDA, Inácio. Votação da PEC 601. Diário da Câmara dos Deputados. Ano LV - n. 015. 27 de janeiro de 2000. Disponível em: < http://imagem.camara.gov.br/Imagem/d/pdf/DCD27JAN2000.pdf\#page=277 >. Acesso em 01 nov. 2017.

BARROSO, Luís Roberto. Curso de direito constitucional contemporâneo: os conceitos fundamentais e a construção do novo modelo - 9. ed. - São Paulo : Saraiva Educação, 2020. 576 p.

BASSUL, José Roberto. O Estatuto da Cidade dez anos depois. Em: BRASIL. Estatuto da Cidade 10 anos: avançar no planejamento e na gestão urbana. - Brasília: Senado Federal, gabinete do Senador Inácio Arruda, 2011. Disponível em: < https://www2.senado.leg.br/bdsf/bitstream/handle/id/385442/Cartilha \%20Estatuto\%20da\%20Cidade\%2010\%20anos.pdf? sequence=1>. Acesso em 01 ago. 2020.

BRASIL. Lei n. 9.300, de 29 de agosto de 1996. Acrescenta parágrafo ao art. $9^{\circ}$ da Lei $n^{\circ} 5.889$, de 8 de junho de 1973, que estatui normas reguladoras do trabalho rural e dá outras providências. Diário Oficial da União, Brasília, DF, 30 ago. 1996 (a).

. Medida provisória n. 1.520, de 24 de setembro de 1996. Dispõe sobre a novação de dívidas e responsabilidades do Fundo de Compensação de Variações Salariais - FCVS; altera o Decreto-lei n. 2.406, de 5 de janeiro de 1988, e as Leis n. 8.004 e 8.100, de 14 de março de 1990, e 5 de dezembro de 1990, respectivamente; e dá outras providências. Diário Oficial da União, Brasília, DF, 25 set. 1996 (b).

. Lei n. 9.514, de 20 de novembro de 1997. Dispõe sobre o Sistema de Financiamento Imobiliário, institui a alienação fiduciária de coisa imóvel e dá outras providências. Diário Oficial da União, Brasília, DF, 21 nov. 1997(a).

. Decreto n. 2.450, de 30 de dezembro de 1997. Prorroga a validade da inscrição em Restos a Pagar de Programas a cargo do Ministério do Planejamento e Orçamento. Diário Oficial da União, Brasília, DF, 21 nov. 1997(b).

. Decreto Legislativo n. 42, de 20 de maio de 1998. Aprova o texto do Acordo sobre a Construção e Utilização de um Prédio para a Ampliação das Instalações da Embaixada do Brasil em Luanda e para Habitação dos Funcionários Diplomáticos, Técnicos e Administrativos, celebrado entre o Governo da República Federativa do Brasil e o Governo da República Popular de Angola, em 28 de janeiro de 1989. Diário Oficial da União, Brasília, DF, 01 jun. 1998 (a).

. Lei n. 9.649, de 27 de maio de 1998. Dispõe sobre a organização da Presidência da República e dos Ministérios, e dá outras providências. Diário Oficial da União, Brasília, DF, 28 maio 1998 (b).

Decreto n. 2.921, de 30 de dezembro de 1998. Prorroga a validade da inscrição em Restos a Pagar de Programas a cargo do Ministério do Planejamento e Orçamento. Diário Oficial da União, Brasília, DF, 31 dez. 1998 (c). 
Lei n. 9.785, de 29 de janeiro de 1999. Altera o Decreto-Lei n. 3.365, de 21 de junho de 1941 (desapropriação por utilidade pública) e as Leis n. 6.015, de 31 de dezembro de 1973 (registros públicos) e 6.766, de 19 de dezembro de 1979 (parcelamento do solo urbano). Diário Oficial da União, Brasília, DF, 01 fev. 1999 (a).

Lei n. 9.934, de 20 de dezembro de 1999. Altera a Lei n. 6.015, de 31 de dezembro de 1973, para acrescentar dispositivos sobre a redução de despesas cartorárias com as escrituras públicas e os registros imobiliários para a aquisição de imóvel construído pelo sistema de mutirão nos programas habitacionais para famílias de baixa renda. Diário Oficial da União, Brasília, DF, 21 dez. 1999 (b).

Decreto n. 3.298, de 20 de dezembro de 1999. Regulamenta a Lei n. 7.853, de 24 de outubro de 1989, dispõe sobre a Política Nacional para a Integração da Pessoa Portadora de Deficiência, consolida as normas de proteção, e dá outras providências. Diário Oficial da União, Brasília, DF, 21 dez. 1999 (c).

Constituição Federal (1988). Emenda Constitucional n. 26, de 14 de fevereiro de 2000. Altera a redação do art. $6^{\circ}$ da Constituição Federal. Diário Oficial da União, Brasília, DF, 15 fev. 2000 (a).

Constituição Federal (1988). Emenda Constitucional n. 31, de 14 de dezembro de 2000. Altera o Ato das Disposições Constitucionais Transitórias, introduzindo artigos que criam o Fundo de Combate e Erradicação da Pobreza. Diário Oficial da União, Brasília, DF, 18 dez. 2000 (b).

Lei n. 10.150, de 21 de dezembro de 2000. Dispõe sobre a novação de dívidas e responsabilidades do Fundo de Compensação de Variações Salariais - FCVS; altera o Decreto-Lei no 2.406, de 5 de janeiro de 1988, e as Leis nos 8.004, 8.100 e 8.692, de 14 de março de 1990, 5 de dezembro de 1990, e 28 de julho de 1993, respectivamente; e dá outras providências. Diário Oficial da União, Brasília, DF, 22 dez. 2000 (c).

. Lei n. 10.188, de 12 de fevereiro de 2001. Diário Oficial da União, Brasília, DF, Cria o Programa de Arrendamento Residencial, institui o arrendamento residencial com opção de compra e dá outras providências. Diário Oficial da União, Brasília, DF, 14 fev. 2001 (a).

Lei n. 10.251, de 10 de julho de 2001. Regulamenta os arts. 182 e 183 da Constituição Federal, estabelece diretrizes gerais da política urbana e dá outras providências. Diário Oficial da União, Brasília, DF, 11 jul. 2001 (b).

Medida Provisória n. 2.158, de 24 de agosto de 2001. Altera a legislação das Contribuições para a Seguridade Social - COFINS, para os Programas de Integração Social e de Formação do Patrimônio do Servidor Público - PIS/PASEP e do Imposto sobre a Renda, e dá outras providências. Diário Oficial da União, Brasília, DF, 27 ago. 2001 (c).

Medida Provisória n. 2.181, de 24 de agosto de 2001. Dispõe sobre operações financeiras entre o Tesouro Nacional e as entidades que menciona, e dá outras providências. Diário Oficial da União, Brasília, DF, 27 ago. 2001 (d).

Medida Provisória n. 2.197, de 24 de agosto de 2001. Dispõe sobre a adoção de medidas relacionadas com o Sistema Financeiro da Habitação - SFH, altera as Leis nos 4.380, de 21 de agosto de 1964, 8.036, de 11 de maio de 1990, e 8.692, de 28 de julho de 1993, e dá outras providências. Diário Oficial da União, Brasília, DF, 27 ago. 2001 (e).

Medida Provisória n. 2.212, de 30 de agosto de 2001. Cria o Programa de Subsídio à Habitação de Interesse Social - PSH, e dá outras providências. Diário Oficial da União, Brasília, DF, 31 ago. 2001 (f). 
. Medida Provisória n. 2.218, de 05 de setembro de 2001. Dispõe sobre a remuneração dos militares do Distrito Federal e dá outras providências. Diário Oficial da União, Brasília, DF, 05 set. 2001 (g).

Decreto n. 4.156, de 11 de março de 2002. Regulamenta a Medida Provisória no 2.212, de 30 de agosto de 2001, que cria o Programa de Subsídio à Habitação de Interesse Social - PSH e dá outras providências. Diário Oficial da União, Brasília, DF, 12 mar. 2002 (a).

Decreto n. 4.229, de 13 de maio de 2002. Dispõe sobre o Programa Nacional de Direitos Humanos $\overline{\mathrm{PNDH}}$, instituído pelo Decreto no 1.904, de 13 de maio de 1996, e dá outras providências. Diário Oficial da União, Brasília, DF, 14 mai. 2002 (b).

Decreto n. 4.494, de 3 de dezembro de 2002. Regulamenta o Imposto sobre Operações de Crédito, Câmbio e Seguro, ou relativas a Títulos ou Valores Mobiliários - IOF. Diário Oficial da União, Brasília, DF, 04 dez. 2002 (c).

. Decreto n. 4.675, de 16 de abril de 2003. Regulamenta o Programa Nacional de Acesso à Alimentação - "Cartão Alimentação", criado pela Medida Provisória no 108, de 27 de fevereiro de 2003. Diário Oficial da União, Brasília, DF, 17 abr. 2003 (a).

. Lei n. 10.741, de 1 ㅇ de outubro de 2003. Dispõe sobre o Estatuto do Idoso e dá outras providências. Diário Oficial da União, Brasília, DF, 03 out. 2003 (b).

. Lei n. 10.840, de 11 de fevereiro de 2004. Cria o Programa Especial de Habitação Popular - PEHP, e dá outras providências. Diário Oficial da União, Brasília, DF, 12 fev. 2004 (a).

. Lei $\mathbf{n} . \mathbf{1 0 . 8 8 5}$, de 17 de junho de 2004. Altera a Lei $n=10.150$, de 21 de dezembro de 2000, que dispõe sobre a novação de dívidas e responsabilidades do Fundo de Compensação de Variações Salariais, e dá outras providências. Diário Oficial da União, Brasília, DF, 18 jun. 2004 (b).

. Decreto de 27 de agosto de 2004. Institui Grupo Executivo Interministerial para articular, viabilizar e acompanhar as ações necessárias ao desenvolvimento sustentável do Município de Alcântara, Maranhão, e dá outras providências. Diário Oficial da União, Brasília, DF, 30 ago. 2004 (c).

. Lei n. 10.998, de 15 de dezembro de 2004. Altera o Programa de Subsídio à Habitação de Interesse Social. Diário Oficial da União, Brasília, DF, 16 dez. 2004 (d).

Decreto n. 5.345, de 18 de janeiro de 2005. Dispõe sobre contratos do Programa de Subsídio à Habitação de Interesse Social - PSH. Diário Oficial da União, Brasília, DF, 19 jan. 2005 (a).

. Lei n. 11.124, de 16 de junho de 2005. Dispõe sobre o Sistema Nacional de Habitação de Interesse Social - SNHIS, cria o Fundo Nacional de Habitação de Interesse Social - FNHIS e institui o Conselho Gestor do FNHIS. Diário Oficial da União, Brasília, DF, 17 jun. 2005 (b).

Lei n. 11.308, de 23 de maio de 2006. Abre crédito extraordinário, em favor do Ministério das Cidades, no valor de R\$ 890.000.000,00, para os fins que especifica. Diário Oficial da União, Brasília, DF, 24 mai. 2006 (a).

Decreto n. 5.796, de 6 de junho de 2006. Regulamenta a Lei n. 11.124, de 16 de junho de 2005, que dispõe sobre o Sistema Nacional de Habitação de Interesse Social - SNHIS, cria o Fundo Nacional de Habitação de Interesse Social - FNHIS e institui o Conselho Gestor do FNHIS. Diário Oficial da União, Brasília, DF, 07 jun. 2006 (b). 
. Lei n. 11.324, de 19 de julho de 2006. Altera dispositivos das Leis n. 9.250, de 26 de dezembro de $1995,8.212$, de 24 de julho de 1991, 8.213, de 24 de julho de 1991, e 5.859, de 11 de dezembro de 1972; e revoga dispositivo da Lei n. 605, de 5 de janeiro de 1949. Diário Oficial da União, Brasília, DF, 20 jul. 2006 (c).

Decreto n. 5.892, de 12 de setembro de 2006. Acresce parágrafo ao art. 40 do Decreto no 4.840, de 17 de setembro de 2003, que regulamenta a Medida Provisória no 130, de 17 de setembro de 2003, que dispõe sobre a autorização para desconto de prestações em folha de pagamento. Diário Oficial da União, Brasília, DF, 13 set. 2006 (d).

Lei n. 11.355, de 19 de outubro de 2006. Dispõe sobre a criação da Carreira da Previdência, da Saúde e do Trabalho, do Plano de Carreiras e Cargos de Ciência, Tecnologia, Produção e Inovação em Saúde Pública da Fiocruz, do Plano de Carreiras e Cargos do Inmetro, do Plano de Carreiras e Cargos do IBGE e do Plano de Carreiras e Cargos do INPI; o enquadramento dos servidores originários das extintas Tabelas de Especialistas no Plano de Classificação de Cargos, de que trata a Lei no 5.645, de 10 de dezembro de 1970, e no Plano Único de Classificação e Retribuição de Cargos e Empregos, de que trata a Lei no 7.596, de 10 de abril de 1987; a criação do Plano de Carreiras dos Cargos de Tecnologia Militar, a reestruturação da Carreira de Tecnologia Militar, de que trata a Lei no 9.657, de 3 de junho de 1998; a criação da Carreira de Suporte Técnico à Tecnologia Militar; a extinção da Gratificação de Desempenho de Atividade de Tecnologia Militar - GDATM; e a criação da Gratificação de Desempenho de Atividade Técnico-Operacional em Tecnologia Militar - GDATEM; a alteração da Gratificação de Desempenho de Atividade de Controle e Segurança de Tráfego Aéreo - GDASA, de que trata a Lei no 10.551, de 13 de novembro de 2002; a alteração dos salários dos empregos públicos do Hospital das Forças Armadas HFA, de que trata a Lei no 10.225, de 15 de maio de 2001; a criação de cargos na Carreira de Defensor Público da União; a criação das Funções Comissionadas do INSS - FCINSS; o auxílio-moradia para os servidores de Estados e Municípios para a União, a extinção e criação de cargos em comissão; e dá outras providências. Diário Oficial da União, Brasília, DF, 20 out. 2006 (e).

Decreto de 25 de outubro de 2006. Constitui Grupo de Trabalho Interministerial - GTI, com a finalidade de elaborar estudos e apresentar propostas de políticas públicas para a inclusão social da população em situação de rua, conforme disposto na Lei n. 8.742, de 07 de dezembro de 1993, e dá outras providências. Diário Oficial da União, Brasília, DF, 26 out. 2006 (f).

. Decreto n. 5.955, de 07 de novembro de 2006. Dá nova redação ao art. 7o do Anexo I do Decreto no 5.719, de 13 de março de 2006, que aprova a Estrutura Regimental e o Quadro Demonstrativo dos Cargos em Comissão e das Funções Gratificadas do Ministério do Planejamento, Orçamento e Gestão, e dá outras providências. Diário Oficial da União, Brasília, DF, 08 nov. 2006 (g).

Lei n. 11.434, de 28 de dezembro de 2006. Acresce art. 18-A à Lei no 8.177, de 10 de março de 1991, que estabelece regras para a desindexação da economia; altera as Leis nos 10.893, de 13 de julho de 2004, 10.833, de 29 de dezembro de 2003, e 11.322, de 13 de julho de 2006; e dá outras providências. Diário Oficial da União, Brasília, DF, 29 dez. 2006 (h).

Decreto n. 6.025, de 22 de janeiro de 2007. Institui o Programa de Aceleração do Crescimento $\overline{\mathrm{PAC}}$, o seu Comitê Gestor, e dá outras providências. Diário Oficial da União, Brasília, DF, 22 jan. 2007 (a).

Lei n. 11.481, de 31 de maio de 2007. Dá nova redação a dispositivos das Leis nos 9.636 , de 15 de maio de 1998, 8.666, de 21 de junho de 1993, 11.124, de 16 de junho de 2005, 10.406, de 10 de janeiro de 2002 - Código Civil, 9.514, de 20 de novembro de 1997, e 6.015, de 31 de dezembro de 1973, e dos Decretos-Leis n. 9.760, de 5 de setembro de 1946, 271, de 28 de fevereiro de 1967, 1.876, de 15 de 
julho de 1981, e 2.398, de 21 de dezembro de 1987; prevê medidas voltadas à regularização fundiária de interesse social em imóveis da União; e dá outras providências. Diário Oficial da União, Brasília, DF, 31 maio 2007 (b).

. Lei n. 11.485, de 13 de junho de 2007. Constitui fonte de recursos adicional para ampliação de limites operacionais da Caixa Econômica Federal - CEF. Diário Oficial da União, Brasília, DF, 14 jun. 2007 (c).

Lei n. 11.490, de 20 de junho de 2007. Altera as Leis n. 9.657, de 3 de junho de 1998, 10.480, de 2 de julho de 2002, 11.314, de 3 de julho de 2006, 11.344, de 8 de setembro de 2006, 11.355, 11.356, 11.357 e 11.358, de 19 de outubro de 2006, 8.025, de 12 de abril de 1990, e 8.112, de 11 de dezembro de 1990, 11.457, de 16 de março de 2007, e dá outras providências. Diário Oficial da União, Brasília, DF, 21 jun. 2007 (d).

Decreto n. 6.194, de 22 de agosto de 2007. Aprova a Estrutura Regimental e o Quadro Demonstrativo dos Cargos em Comissão e das Funções Gratificadas do Ministério da Previdência Social e dá outras providências. Diário Oficial da União, Brasília, DF, 23 ago. 2007 (e).

Decreto n. 6.215, de 26 de setembro de 2007. Estabelece o Compromisso pela Inclusão das Pessoas com Deficiência, com vistas à implementação de ações de inclusão das pessoas com deficiência, por parte da União Federal, em regime de cooperação com Municípios, Estados e Distrito Federal, institui o Comitê Gestor de Políticas de Inclusão das Pessoas com Deficiência - CGPD, e dá outras providências. Diário Oficial da União, Brasília, DF, 28 set. 2007 (f).

. Lei n. 11.578, de 26 de novembro de 2007. Dispõe sobre a transferência obrigatória de recursos financeiros para a execução pelos Estados, Distrito Federal e Municípios de ações do Programa de Aceleração do Crescimento - PAC, e sobre a forma de operacionalização do Programa de Subsídio à Habitação de Interesse Social - PSH nos exercícios de 2007 e 2008. Diário Oficial da União, Brasília, DF, 27 nov. 2007 (g).

Decreto n. 6.276, de 28 de novembro de 2007. Discrimina ações do Programa de Aceleração do crescimento - PAC a serem executadas por meio de transferência obrigatória. Diário Oficial da União, Brasília, DF, 29 nov. 2007 (h).

Decreto n. 6.306, de 14 de dezembro de 2007. Regulamenta o Imposto sobre Operações de Crédito, Câmbio e Seguro, ou relativas a Títulos ou Valores Mobiliários - IOF. Diário Oficial da União, Brasília, DF, 17 dez. 2007 (i).

Decreto n. 6.450, de 8 de maio de 2008. Discrimina ações do Programa de Aceleração do crescimento - PAC a serem executadas por meio de transferência obrigatória. Diário Oficial da União, Brasília, DF, 09 mai. 2008 (a).

. Lei $\mathbf{n}$. 11.888, de 24 de dezembro de 2008. Assegura às famílias de baixa renda assistência técnica pública e gratuita para o projeto e a construção de habitação de interesse social e altera a Lei no 11.124, de 16 de junho de 2005. Diário Oficial da União, Brasília, DF, 26 dez. 2008 (b).

Decreto n. 6.820, de 13 de abril de 2009. Institui a Política Nacional para a População em Situação de Rua e seu Comitê Intersetorial de Acompanhamento e Monitoramento, e dá outras providências. Diário Oficial da União, Brasília, DF, 13 abr. 2009 (a).

. Lei n. 11.977, de 7 de julho de 2009. Dispõe sobre o Programa Minha Casa, Minha Vida - PMCMV e a regularização fundiária de assentamentos localizados em áreas urbanas; altera o Decreto-Lei n. 3.365, 
de 21 de junho de 1941, as Leis n. 4.380, de 21 de agosto de 1964, 6.015, de 31 de dezembro de 1973, 8.036, de 11 de maio de 1990, e 10.257, de 10 de julho de 2001, e a Medida Provisória no 2.197-43, de 24 de agosto de 2001; e dá outras providências. Diário Oficial da União, Brasília, DF, 08 jul. 2009 (b).

. Lei n. 12.024, de 27 de agosto de 2009. Dá nova redação aos arts. 4o, 5 o e 80 da Lei no 10.931, de 2 de agosto de 2004, que tratam de patrimônio de afetação de incorporações imobiliárias; dispõe sobre o tratamento tributário a ser dado às receitas mensais auferidas pelas empresas construtoras nos contratos de construção de moradias firmados dentro do Programa Minha Casa, Minha Vida - PMCMV, atribui à Agência Nacional de Telecomunicações - ANATEL as atribuições de apurar, constituir, fiscalizar e arrecadar a Contribuição para o Fomento da Radiodifusão Pública; altera as Leis nos 11.196, de 21 de novembro de 2005, 11.652, de 7 de abril de 2008, 10.833, de 29 de dezembro de 2003, 9.826, de 23 de agosto de 1999, 6.099, de 12 de setembro de 1974, 11.079, de 30 de dezembro de 2004, 8.668, de 25 de junho de 1993, 8.745, de 9 de dezembro de 1993, 10.865, de 30 de abril de 2004, 8.989, de 24 de fevereiro de 1995, e 11.941, de 27 de maio de 2009; e dá outras providências. Diário Oficial da União, Brasília, DF, 28 ago. 2009 (c).

Decreto n. 7.053, de 23 de dezembro de 2009. Institui a Política Nacional para a População em Situação de Rua e seu Comitê Intersetorial de Acompanhamento e Monitoramento, e dá outras providências. Diário Oficial da União, Brasília, DF, 24 dez. 2009 (d).

Medida Provisória n. 478, de 29 de dezembro de 2009. Dispõe sobre a extinção da Apólice do Seguro Habitacional do Sistema Financeiro da Habitação - SH/SFH, altera a legislação tributária relativamente às regras de preços de transferência, e dá outras providências. Diário Oficial da União, Brasília, DF, 29 dez. 2009 (e).

Decreto n. 7.161, de 29 de abril de 2010. Autoriza a permuta de ações entre a União e entidades da administração federal indireta e dá outras providências. Diário Oficial da União, Brasília, DF, 30 abr. 2010 (a).

. Lei n. 12.249, de 11 de junho de 2010. Institui o Regime Especial de Incentivos para o Desenvolvimento de Infraestrutura da Indústria Petrolífera nas Regiões Norte, Nordeste e Centro-Oeste - REPENEC; [...] ajusta o Programa Minha Casa Minha Vida - PMCMV; [...] e dá outras providências. Diário Oficial da União, Brasília, DF, 14 jun. 2010 (b).

Decreto n. 7.366, de 25 de novembro de 2010. Autoriza a integralização de cotas do Fundo Garantidor da Habitação Popular - FGHab. Diário Oficial da União, Brasília, DF, 26 nov. 2010 (c).

Decreto n. 7.367, de 25 de novembro de 2010. Altera o Decreto no 6.144, de 3 de julho de 2007, que regulamenta a forma de habilitação e co-habilitação ao Regime Especial de Incentivos para o Desenvolvimento da Infra-Estrutura - REIDI, instituído pelos arts. 10 a 50 da Lei no 11.488 , de 15 de junho de 2007. Diário Oficial da União, Brasília, DF, 26 nov. 2010 (d).

. Lei n. 12.409, de 25 de maio de 2011.Conversão da Medida Provisória n. 513, de 2010. Autoriza o Fundo de Compensação de Variações Salariais - FCVS, a assumir, na forma disciplinada em ato do Conselho Curador do Fundo de Compensação de Variações Salariais - CCFCVS, direitos e obrigações do Seguro Habitacional do Sistema Financeiro da Habitação - SH/SFH; oferecer cobertura direta a contratos de financiamento habitacional averbados na Apólice do SH/SFH; autoriza o Departamento Nacional de Infraestrutura de Transporte - DNIT a utilizar recursos federais em apoio à transferência definitiva do domínio da malha rodoviária federal para os Estados; altera o Anexo do Plano Nacional de Viação aprovado pela Lei n. 5.917, de 10 de setembro de 1973, e as Leis nos 12.249, de 11 de junho de 2010, 11.887, de 24 de dezembro de 2008, 11.079, de 30 de dezembro de 2004, e 11.314, de 3 de julho de 
2006; revoga a Medida Provisória no 523, de 20 de janeiro de 2011; e dá outras providências. Diário Oficial da União, Brasília, DF, 26. Maio 2011 (a).

. Lei n. 12.415, de 09 de junho de 2011. Acrescenta parágrafo único ao art. 130 da Lei no 8.069, de 13 de julho de 1990 (Estatuto da Criança e do Adolescente), para determinar que alimentos provisórios sejam fixados cautelarmente em favor da criança ou adolescente cujo agressor seja afastado da moradia comum por determinação judicial. Diário Oficial da União, Brasília, DF, 10 jun. 2011 (b).

Decreto n. 7.612, de 17 de novembro de 2011. Institui o Plano Nacional dos Direitos da Pessoa com Deficiência - Plano Viver sem Limite. Diário Oficial da União, Brasília, DF, 18 nov. 2011 (c).

. Lei n. 12.712, de 30 de agosto de 2012. Altera as Leis nos 12.096, de 24 de novembro de 2009, 12.453, de 21 de julho de 2011, para conceder crédito ao Banco Nacional de Desenvolvimento Econômico e Social - BNDES, [...]; e dá outras providências. Diário Oficial da União, Brasília, DF, 31 ago. 2015.

. Lei n. 13.000, de 18 de junho de 2014. Altera as Leis nos 12.096, de 24 de novembro de 2009, que autoriza a concessão de subvenção econômica sob a modalidade de equalização de taxas de juros pela União, e 12.409, de 25 de maio de 2011, que autoriza o Fundo de Compensação de Variações Salariais FCVS a assumir direitos e obrigações do Seguro Habitacional do Sistema Financeiro da Habitação SH/SFH; autoriza a União a conceder empréstimo ao Banco Nacional de Desenvolvimento Econômico e Social - BNDES; autoriza a União a conceder subvenção econômica às unidades produtoras de etanol na região Nordeste; e dá outras providências. Diário Oficial da União, Brasília, DF, 20 jun. 2014.

. Lei n. 13.089, de 12 de janeiro de 2015. Institui o Estatuto da Metrópole, altera a Lei no 10.257, de 10 de julho de 2001, e dá outras providências. Diário Oficial da União, Brasília, DF, 13 jan. 2015 (a).

. Lei n. 13.137, de 19 de junho de 2015. Altera as Leis nos 10.865, de 30 de abril de 2004, para elevar alíquotas da Contribuição para o PIS/Pasep-Importação e da Cofins-Importação, [...] e dá outras providências. Diário Oficial da União, Brasília, DF, 22 jun. 2015 (b).

O que é o PAC? 22/05/2015. Disponível em: < http://www.planejamento.gov.br/servicos/faq/pacprograma-de-aceleracao-do-crescimento/visao-geral/o-que-e-o-pac>. Acesso em: 15 jan. 2017.

CAIXA. Minha Casa Minha Vida 2017: Entenda o que muda no programa. 08/02/2017. Disponível em: <http://www20.caixa.gov.br/Paginas/Noticias/Noticia/Default.aspx?newsID=4550>. Acesso em 01 ago. 2020.

CÂMARA DOS DEPUTADOS. Proposta de Câmara dos Deputados Emenda à Constituição no 601, de 1998 (do Senado Federal) PEC 28j96-SF. Disponível em: <https://www.camara.leg.br/proposicoesWeb/p rop_mostrarintegra;jsessionid=012EC6E2F598B9C637EB50EFE7B0C36B.node1?codteor $=1234598 \&$ filena me=Avulso+-PEC+601/1998>. Acesso em: 15 set. 2017.

DIÁRIO DA CÂMARA DOS DEPUTADOS. Ano LV - no 15. Quarta-Feira, 27 de janeiro de 2000. Brasília DF. Disponível em < http://imagem.camara.gov.br/Imagem/d/pdf/DCD27JAN2000.pdf\#page=277>. Acesso em: 20 jul. 2020.

MASTRODI, Josué; SILVA, Márcia Maria Carvalho da. O direito fundamental social à moradia e a teoria geral do direito. Revista Direitos Fundamentais \& Justiça. Ano 6, no 21, p. 145-162, out./dez. 2012. 
MENCIO, Mariana. As consequências jurídicas advindas da falta de participação popular durante o processo de elaboração e aprovação do plano diretor. Revista MPMG Jurídico. Ano I, n. 4. Belo Horizonte, 2006. Disponível em: <https://aplicacao.mpmg.mp.br/xmlui/bitstream/handle/123456789/ 839/3.2.2\%20As\%20consequencias\%20jur\%C3\%ADdicas. pdf?sequence=1>. Acesso em: 20 jul. 2020.

MONTEIRO, Adriana Roseno; VERAS, Antonio Tolrino de Rezende. O Programa Minha Casa, Minha Vida e a Produção do Espaço Urbano na Cidade de Boa Vista - RR. Revista de Direito da Cidade, vol.07, no 03. ISSN 2317-7721 pp.1180-1199.

MOREIRA, Camilla Fernandes; CASTRO, Marcus Faro de. A Análise Jurídica da Política Econômica aplicada ao Programa Minha Casa, Minha Vida: um estudo de caso de Brasília (2014-2017). Revista de Direito da Cidade, vol. 12, no 2. ISSN 2317-7721. pp.528-564.

ONU, Department of Economic and Social Affairs, Population Division. 2014. World Urbanization Prospects: The 2014 Revision, CD-ROM Edition. Disponível em: < https://esa.un.org/unpd/wup/CDROM/>. Acesso em: 20 ago. 2017.

Declaração de Istambul sobre Assentamentos Humanos. 1996. Disponível em: $<$ http://pfdc.pgr.mpf.mp.br/atuacao-e-conteudos-de-apoio/legislacao/moradiaadequada/declaracoes/declaracao-de-istambul-sobre-assentamentos-humanos $>$. Acesso em: 15 nov. 2017.

PAC. Sobre o PAC. Disponível em: < http://www.pac.gov.br/sobre-o-pac >. Acesso em: 24 jul. 2017.

REIS, Émilien Vilas Boas; VENÂNCIO, Stephanie Rodrigues. O Direito à Cidade e a Participação Popular no Planejamento Urbano Municipal. Revista de Direito da Cidade, vol. 08, no 4. ISSN 2317-7721 pp. 1205-1230.

ROMAGNOLI, Alexandre José. O Programa “Minha Casa, Minha Vida” na política habitacional brasileira: continuidades, inovações e retrocessos. Dissertação (Mestrado em Ciência Política) Universidade Federal de São Carlos, São Carlos, 2012.

SANTIN, Janaína Rigo; PEDRINI, Maristela; COMIRAN, Rafaela. A Política Nacional dos Resíduos Sólidos e os Municípios Brasileiros: Desafios e Possibilidades. Revista de Direito da Cidade, vol. 09, no 2. ISSN 2317-7721 pp. 556-580. 